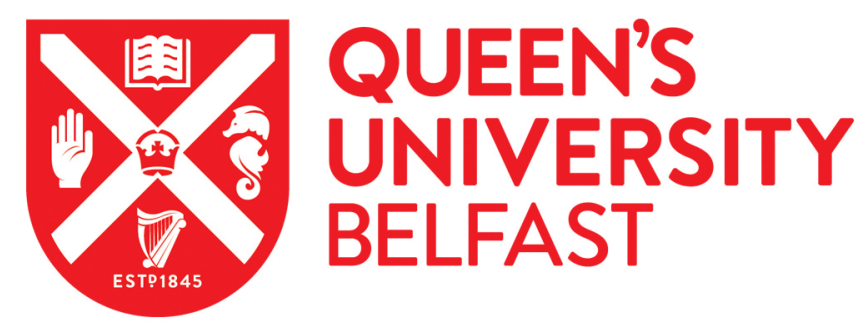

\title{
Supplier involvement in eco-innovation: The co-development of electric, hybrid and fuel cell technologies within the Japanese automotive industry
}

Potter, A., \& Graham, S. (2019). Supplier involvement in eco-innovation: The co-development of electric, hybrid and fuel cell technologies within the Japanese automotive industry. Journal of Cleaner Production, 210, 12161228. https://doi.org/10.1016/j.jclepro.2018.10.336

\section{Published in:}

Journal of Cleaner Production

\section{Document Version:}

Peer reviewed version

Queen's University Belfast - Research Portal:

Link to publication record in Queen's University Belfast Research Portal

\section{Publisher rights}

Copyright 2018 Elsevier Ltd.

This manuscript is distributed under a Creative Commons Attribution-NonCommercial-NoDerivs License

(https://creativecommons.org/licenses/by-nc-nd/4.0/), which permits distribution and reproduction for non-commercial purposes, provided the author and source are cited.

\section{General rights}

Copyright for the publications made accessible via the Queen's University Belfast Research Portal is retained by the author(s) and / or other copyright owners and it is a condition of accessing these publications that users recognise and abide by the legal requirements associated with these rights.

Take down policy

The Research Portal is Queen's institutional repository that provides access to Queen's research output. Every effort has been made to ensure that content in the Research Portal does not infringe any person's rights, or applicable UK laws. If you discover content in the

Research Portal that you believe breaches copyright or violates any law, please contact openaccess@qub.ac.uk. 


\title{
Supplier involvement in eco-innovation:
}

\author{
The co-development of electric, hybrid and fuel cell technologies within the
} Japanese automotive industry

\begin{abstract}
:
Recently, automakers have invested heavily in alternative fuel technologies to reduce carbon dioxide $\left(\mathrm{CO}_{2}\right)$ and nitrogen oxide $\left(\mathrm{NO}_{\mathrm{x}}\right)$ emissions from vehicles. Yet we know comparatively little about how automakers work collaboratively with their suppliers to develop interorganizational eco-innovations. We address this research gap and contribute to the ecoinnovation literature by investigating whether suppliers' eco-innovation capabilities in electric, hybrid, and fuel cell technologies influence the degree of eco-innovation co-patenting between Toyota and its suppliers. We also expand research in the strategic alliance literature by exploring the moderating effects of alliance partner diversity. To test our research hypotheses we use data from firms in the Toyota supplier association together with negative binomial and zero-inflated negative binomial regression models. Our empirical results demonstrate that supplier electric capabilities and supplier hybrid capabilities are positively related to the occurrence of eco-innovation co-patents. However, supplier fuel cell capabilities have no effect on eco-innovation co-patenting, especially as firms often choose to develop this technology inhouse. Moreover, alliance partner diversity has a negative moderating effect on the relationships between supplier electric capabilities, supplier hybrid capabilities, and ecoinnovation co-patents. Finally, we evaluate how our findings from the Toyota supplier association compare to similar Japanese automakers and their supplier networks.
\end{abstract}

Keywords: supplier involvement; eco-innovation; strategic alliances; Toyota supplier association; electric vehicle; hybrid engine; hydrogen fuel cell.

Highlights:

- We investigate the determinants of inter-organizational eco-innovation.

- Identify impact of supplier eco-innovation capabilities in electric, hybrid, and fuel cells.

- Discuss the moderating effects of alliance partner diversity.

- Hypotheses are tested using firms that supply parts to Toyota and Japanese automakers.

\section{Introduction}


The automotive industry is undergoing a crucial transformation in order to decrease carbon dioxide $\left(\mathrm{CO}_{2}\right)$ and nitrogen oxide $\left(\mathrm{NO}_{\mathrm{x}}\right)$ emissions (Nanaki and Koroneos, 2013). Research has shown that the transportation sector is one of the main sources of $\mathrm{CO}_{2}$ emissions and this trend is likely to increase in the future due to the increasing demand for vehicles in emerging economies (Garcia et al., 2017). Moreover, automakers have been placed under further pressure to invest in alternative fuel vehicles as a result of the recent VW diesel scandal related to $\mathrm{NO}_{\mathrm{x}}$ emissions (Lee et al., 2018). In response to growing stakeholder pressure, an increasing number of firms have developed eco-innovations to address environmental concerns and reduce the impact their products and processes have on the environment (Sarkis et al., 2010). Eco-innovation is an environmental practice that seeks to reduce the environmental impact of a product by incorporating environmental considerations into decisions relating to different stages of the product life cycle (MacDonald and She, 2015).

However, the majority of studies have focused on the development of eco-innovations within firms, with little consideration for how inter-organizational eco-innovations are generated in collaboration with organizations from the supplier network (Roscoe et al., 2016). The Natural Resource Based View (NRBV) highlights the importance of engagement with key supply chain stakeholders during the implementation of advanced environmental practices such as eco-innovation (Hart and Dowell, 2011). Recent research is beginning to explore the interfaces between the eco-innovation and supply chain fields by studying how firms involve their suppliers into the process of developing inter-organizational eco-innovations (Pacheco et al., 2017). In particular, Roscoe et al. (2016) highlights that comparatively little is known about the determinants of inter-organizational eco-innovations and the role played by strategic alliances within complex supplier networks. Moreover, this research area is also of practical importance as managers and policy makers are keen to understand how Toyota, its suppliers, and other Japanese automakers were able to develop a sustainable competitive advantage across all three alternative fuel platforms within the automotive industry (Borgstedt et al., 2017). Although many in the practitioner literature have encouraged managers to develop ecoinnovations (Xavier et al., 2017), few are aware of the mechanisms that drive the development of inter-organizational eco-innovations within supplier networks.

We seek to address this research gap and contribute to the eco-innovation literature by undertaking one of the first empirical studies of the determinants of inter-organizational ecoinnovation using co-patenting statistics between automakers and the firms in their supplier network. Consequently, we aim to investigate the following research question: What is the effect of supplier eco-innovation capabilities on the occurrence of inter-organizational eco- 
innovation co-patents, and how is this relationship moderated by alliance partner diversity? Using firm-level data from the Toyota supplier association we identify that supplier electric capabilities and supplier hybrid capabilities are positively related to the occurrence of ecoinnovation co-patents. This supports recent research within the eco-innovation literature that highlights the important contribution supplier eco-innovation capabilities make to the codevelopment of green technologies between automakers and their suppliers (Roscoe et al., 2016; Borgstedt et al., 2017). However, supplier fuel cell capabilities are not found to be associated with eco-innovation co-patenting within the Toyota supplier association, which may be due to Toyota's strategic decision to primarily develop this radical innovation in-house with a limited amount of supplier involvement (Ehsani et al., 2018).

We also contribute to debates within the strategic alliance literature surrounding the positive and negative effects of alliance partner diversity on organizational innovation (Sampson, 2007; Cui and O'Connor, 2012; Leeuw et al. 2014). We expand this literature by undertaking the first empirical investigation of how strategic alliances influence the development of inter-organizational eco-innovations within a supplier network (Jiang et al., 2010; Popadic et al., 2016). Contrary to expectations, our empirical results demonstrate that alliance partner diversity has a negative moderating effect on the relationships between supplier electric capabilities, supplier hybrid capabilities, and eco-innovation co-patenting. These findings reveal that firms may be struggling to manage a complex network of alliance partners during the process of developing inter-organizational eco-innovations (Leeuws et al., 2014). Our further analysis reveals that strategic alliances can facilitate eco-innovation co-patenting, but only when firms use bilateral one-to-one strategic alliances to maintain strong ties with individual alliance partners (Roscoe et al., 2016). Finally, to improve the robustness of our findings we explore how the results from the Toyota supplier association compare to similar automotive supplier networks managed by Honda, Daihatsu, Suzuki, Mitsubishi, and Nissan.

\section{Theoretical background}

\subsection{The Natural Resource-Based view (NRBV) and eco-innovations}


The NRBV considers the potential for firms to generate unique sources of competitive advantage through engagement with the natural environment (Hart and Dowell, 2011). This engagement can be expressed through a range of practices targeted at either reducing the environmental impact generated by the products themselves throughout their life cycle or the production processes through which they are developed (Sarkis et al., 2010). Eco-innovation is a product-focussed practice aimed at designing and developing materials, components, and products that have a beneficial impact on the environment (MacDonald and She, 2015; Xavier et al., 2017). Eco-innovation has become a prominent practice in the context of the automotive industry because of stakeholder pressures on firms to take responsibility for the environmental impacts generated by their products (Aloise and Macke, 2017). Many argue that alternative fuel vehicles and their components and modules are regarded as eco-innovations because they are highly innovative new products that have a significant impact on the environment by reducing $\mathrm{CO}_{2}$ and $\mathrm{NO}_{\mathrm{x}}$ emissions from vehicles (Borgstedt et al., 2017). According to the $\mathrm{NRBV}$, the implementation of product focused environmental practices such as eco-innovation should be supported by engagement with suppliers (Hart and Dowell, 2011). Applying this perspective, we propose that suppliers' eco-innovation capabilities can be defined as their ability to research, design, develop, and manufacture eco-innovation technologies (Bossle et al., 2016). This supply-side eco-innovation is often an important, but largely overlooked, reason for the development of different alternative fuel platforms in the automotive industry.

In parallel with this trend, research from the supply chain management literature has found that involving suppliers in the innovation process can enhance the potential for positive outcomes to emerge from inter-organizational NPD projects (Liker and Choi, 2004; Aoki and Lennerfors, 2013). Supplier involvement in NPD enables firms to access supplier resources and innovation capabilities in a way that is conducive to the implementation of eco-innovation (Lawson et al., 2015). In particular, studies have found that Toyota frequently uses early supplier involvement to integrate its suppliers into the fuzzy front end of the NPD process (Dyer and Nobeoka, 2000; Aoki and Lennerfors, 2013). Involving suppliers into an NPD project is a mechanism through which firms can access suppliers' innovation capabilities, facilitate inter-organizational problem-solving, and encourage inter-firm knowledge sharing (Lawson et al., 2015). Hult et al. (2004) argue that supplier innovation capabilities can be regarded as the capability to design, develop, and launch innovative new products and processes into the market. However, to date, the majority of studies that examine the development of eco-innovations within the automotive industry have focused on the R\&D 
efforts of automakers, with little consideration for the eco-innovation capabilities of automotive suppliers (Borgstedt et al., 2017).

\subsection{Determinants of eco-innovation co-patenting: Supplier eco-innovation capabilities}

We follow a similar approach to Xavier et al (2017) by reviewing the literature on ecoinnovation, supply chain management, and strategic alliances to identify some of the key factors that influence the development of inter-organizational eco-innovations. Following a systematic literature review approach outlined by Denyer and Tranfield (2009) we then formulated our research question, identified relevant papers, selected and evaluated the papers, analysed and synthesized the findings, and then reported our results (Xavier et al., 2017). This systematic literature review approach forms the backbone of our literature review, conceptual framework, and research hypotheses. Drawing upon the eco-innovation and supplier involvement literatures, this paper seeks to evaluate whether supplier eco-innovation capabilities have a positive effect on the development of eco-innovation co-patents and how this relationship is influenced by alliance partner diversity (Lawson et al., 2015). In particular, we focus on alternative fuel platforms as a window to investigate the involvement of suppliers in the process of developing inter-organizational eco-innovations. Consequently, we develop a conceptual framework (Fig. 1) that illustrates how supplier eco-innovations in electric, hybrid, and fuel cell technologies affect eco-innovation co-patenting, as represented by hypotheses 1 ,

2 , and 3 respectively. We also examine how these relationships are influenced by the moderating effect of alliance partner diversity (i.e. hypotheses $4 \mathrm{a}, 4 \mathrm{~b}$, and $4 \mathrm{c}$ ). Each of these research hypotheses will now be discussed in more detail.

$$
<<\text { insert Figure } 1 \text { here }>>
$$

Supplier electric capabilities: Following Zapata and Nieuwenhuis (2010), we argue that electric vehicle technologies are radical innovations because they represent a significant departure from the dominant design within the automotive industry and they involve competence-destroying changes to the existing internal combustion engine technology. Although automakers and their suppliers continued to improve electric vehicle technology throughout the twentieth century, it was not until the 1990s that they began to accelerate the development of electric vehicle innovations in response to new environmental regulations such as the California Zero Emission Regulation (Gunther et al., 2015). Research by Borgstedt et al (2017) has shown that improvements by automotive suppliers in electric motor efficiency, 
battery capacity, power transmission, and software have led to substantial improvements in the environmental performance of electric vehicles.

Many Japanese automakers and their suppliers began to invest extensively in electric vehicle technology in the 1990s (Chan, 2007). For example, it has been well documented that Toyota undertook extensive engagement and collaboration with key suppliers throughout the development of its electric vehicle powertrain systems (Gunther et al., 2015). In order to design and develop the Toyota RAV4 EV and iQ EV, Toyota collaborated with firms within its supplier association who possessed advanced capabilities in electric vehicle technologies (Toyota, 2016). Research has also shown that other automakers in Japan such as Honda and Nissan have adopted a similar approach by working collaboratively with suppliers to codevelop advanced lithium-ion batteries, battery components, and battery management systems (Garcia et al., 2017). In particular, Japanese automakers have benefited from a local supply base with advanced electric capabilities in battery technology, such as GS Yuasa International, Panasonic, and Primearth EV Energy (Borgstedt et al., 2017). This leads us to the following research hypothesis:

HP1. Supplier electric capabilities are positively associated with the occurrence of interorganizational eco-innovation co-patents.

Supplier hybrid capabilities: Conversely, hybrid vehicles provide a unique context, as they combine the benefits of a mature technology - the internal combustion engine - with a radical innovation, the hybrid engine platform that was developed by Toyota (Nanaki and Koroneos, 2013; Garcia et al., 2017). Toyota first began experimenting with hybrid vehicle technology in 1968, but it was not until 1993, when it established the G21 Project, that it began to develop the hybrid technology required for the Toyota Prius that would generate a two-fold improvement in the fuel efficiency of conventional engine technology (Toyota, 2016). The Toyota Hybrid System (THS) is the main platform for the Toyota Prius vehicle and it consists of an integrated electric motor and a generator that is linked to a power split device, which integrates series and parallel hybrid systems (Matsuo et al., 2016).

Wilhelm and Kohlbacher (2011) argue that the hybrid synergy drive system in the Toyota Prius vehicle represents a multi-technology hybrid innovation that is only possible through close collaboration and co-patenting with suppliers. During the 2000s and 2010s, Toyota 
continued to work closely with its suppliers to design and develop the fourth-generation Toyota Prius that had higher battery capacity, longer range, greater fuel economy, reduced weight, and lower component costs (Matsuo et al., 2016). In a similar manner, during the 2000s, many Japanese automakers developed a second mover advantage by launching their own hybrid vehicles using components and technologies developed by automotive suppliers in Japan (Chan, 2007). In particular, the expansion in Japan of specialist suppliers of hybrid engine components made them very attractive partners for inter-organizational eco-innovation with different automakers. Consequently, the following research hypothesis is proposed:

HP2. Supplier hybrid capabilities are positively associated with the occurrence of interorganizational eco-innovation co-patents.

Supplier fuel cell capabilities: However, many argue that hybrid engine technology may not be the dominant design of the future, especially as it could be a bridging platform before the widespread adoption of hydrogen fuel cell vehicles (Hellman and Hoed, 2007). In particular, Zapata and Nieuwenhuis (2010) emphasize that hydrogen fuel cell vehicles are radical innovations that have the potential to significantly disrupt conventional combustion engine technology (Chan, 2007). In the 2000s, Toyota further developed and tested the fuel cell engine by using an extracted hydrogen form of methanol, high-pressure hydrogen storage tanks, integrating secondary batteries, and a new power control unit (Toyota, 2016). This long-term investment in this radical eco-technology culminated in 2015 with the launch of the Toyota Mirai, the first mass-produced hydrogen fuel cell vehicle that emits zero $\mathrm{CO}_{2}$ emissions.

Past studies within the supplier involvement literature have also revealed that involving suppliers that have developed radical innovations, such as hydrogen fuel cell technologies, enables firms to better understand the latest scientific research and patented innovations (Menguc et al., 2014). Research suggests that without the involvement of suppliers with specialist capabilities in fuel cell technologies, many Japanese automakers would have struggled to develop inter-organizational fuel cell innovations (Borgstedt et al., 2017). For example, firms such as Hitachi Automotive Systems and Toray Industries helped to develop a range of fuel cell technologies for Japanese automakers, including fuel cell electrolyte membranes, solid oxide fuel cells, and fuel cell gas diffusion layers. Accordingly, we propose the following research hypothesis: 
HP3. Supplier fuel cell capabilities are positively associated with the occurrence of interorganizational eco-innovation co-patents.

\subsection{The moderating role of alliance partner diversity}

According to the relational view of the firm, an organization can also develop a sustainable competitive advantage from its buyer-supplier relationships with external partners (Dyer and Singh, 1998). Within the strategic alliance literature, research argues that organizations are focusing more on how they can manage a portfolio of alliance partners to facilitate the development of electric, hybrid, and hydrogen fuel cell platforms (Hoed, 2007; Gunther et al., 2015). Alliance partner diversity is an important measure in the strategic alliance literature, as it captures the number of strategic alliances a firm has with external organizations (Jiang et al 2010; Popadic et al., 2016). In particular, a recent debate has emerged within the strategic alliance literature concerning the moderating effects of alliance partner diversity on organizational innovations (Sampson, 2007; Cui and O'Connor, 2012; Leeuw et al. 2014).

In a recent systematic review of the eco-innovation literature, Pacheco et al (2017) identified that collaborative relationships and strategic alliances with supply chain partners can help to facilitate the eco-innovation process. In particular, the moderating effect of alliance partner diversity is likely to be more pronounced within inter-organizational eco-innovation projects that are developing electric, hybrid, and fuel cell technologies (Rizzi et al., 2014). First, to overcome the high costs of developing electric vehicle technologies many firms have developed large portfolios of alliance partners that help firms to learn how to utilize their electric capabilities to jointly develop co-patents with automakers (Golembiewski et al., 2015). Second, previous research that has studied the co-development of hybrid engine technologies has also found that strategic alliances provide an effective inter-organizational governance mechanism that enables firms and automakers to share their hybrid innovation capabilities (Liker and Choi, 2004). Third, as firms across the supplier network have committed substantial resources to developing fuel cell technologies, then they are more likely to co-patent with automakers when strategic alliances are used to prevent opportunistic behaviour (Jiang et al., 2010). We therefore propose the following hypotheses:

HP4a. Alliance partner diversity has a positive moderating effect on the relationship between supplier electric capabilities and inter-organizational eco-innovation co-patenting.

HP4b. Alliance partner diversity has a positive moderating effect on the relationship between supplier hybrid capabilities and inter-organizational eco-innovation co-patenting. 
HP4c. Alliance partner diversity has a positive moderating effect on the relationship between supplier fuel cell capabilities and inter-organizational eco-innovation co-patenting.

\section{Research methodology}

\subsection{Research setting: The Toyota supplier association}

We followed a two-stage approach to investigate our research hypotheses using data from Toyota and the Japanese automotive industry. In the first stage, we tested our research hypotheses using data from firms within the Toyota supplier association. From a strategic perspective, Toyota has pursued a long-term philosophy by developing alternative fuel vehicles for different market segments within the automotive industry (Fig. 2) (Toyota; 2016). Recently, Toyota (2016) provided a comprehensive list of all the firms in its supplier association accompanied by a detailed breakdown of each of the components and modules they provide for Toyota's vehicles. The Toyota supplier association contains 219 firms that provide the components used during the production process of its vehicles. As we are focusing exclusively on firms within the supplier association with eco-innovation capabilities in alternative fuel technologies, we only examine the 143 firms that have registered patents in electric, hybrid, and fuel cell technologies in the past four years. This ensures that we focus our analysis on the firms in the supplier association that have developed eco-innovation capabilities to unravel their effect on inter-organizational eco-innovation. In the second stage of our empirical analysis, we then compared the results from the Toyota supplier association to similar supplier networks operated by Honda, Daihatsu, Suzuki, Mitsubishi, and Nissan.

$$
<<\text { Insert Figure } 2 \text { here }>>
$$

\subsection{Data analysis}

To explore our research hypotheses, we used negative binomial regression models that were designed specifically to be used with patent count data (Woolridge, 2013; Bellamy et al., 2014). Moreover, as we have a dependent variable that has an over-dispersed distribution with a variance that is greater than its mean, then a negative binomial model is the most appropriate choice (Greene, 2011). The negative binomial regression model can be expressed as follows (Cameron and Trivedi, 2010): 


$$
\begin{aligned}
\operatorname{Prob}\left(Y=y_{i} \mathrm{I} x_{i}\right) & =\frac{\Gamma\left(\theta+y_{i}\right)}{\Gamma\left(y_{i}+1\right) \Gamma(\theta)} r_{i}^{y_{i}}\left(1-r_{i}\right)^{\theta}, \\
\lambda_{i} & =\exp \left(x_{i}^{\prime} \beta\right), \\
r_{i} & =\lambda_{i}\left(\theta+\lambda_{i}\right) .
\end{aligned}
$$

Negative binomial regression models use maximum likelihood estimation, where $y_{i}$ represents the dependent variable measured as count data, $x_{i}$ refers to the explanatory variables, and $\beta$ are the model coefficients. Specifically, we produced separate empirical analysis for each of our explanatory variables, supplier electric capabilities, supplier hybrid capabilities, and supplier fuel cell capabilities, and these are presented in Tables 2, 3, and 4. In addition, we also included a correlation matrix that is depicted in Table 1.

\section{$<<$ Insert table 1 here $>>$}

However, Greene (2011) argues that negative binomial regression models can sometimes mis-specify the effect of zero observations, and therefore results from zero-inflated negative binomial regression models should also be reported. Following Cameron and Trivedi (2010), the zero-inflated negative binomial model has a density that can be expressed as follows:

$$
f(y)=\left\{\begin{array}{cc}
f_{1}(0)+\left\{1-f_{1}(0)\right\} f_{2}(0) & \text { if } y=0 \\
\left\{1-f_{1}(0)\right\} f_{2}(y) & \text { if } y \geq 1
\end{array}\right.
$$

In the above equation, the probability $f_{1}(0)$ may be a constant or parameterized using a binomial model. Accordingly, if a binary process has a value of 0 and a probability of $f_{1}(0)$ then $y=0$ (Cameron and Trivedi, 2010). However, if the binary process has a value of 1 and its probability of $f_{1}(1)$ then $y$ will be a non-negative integer count value that is derived from a count density. In other words, the zero counts can occur from the binary process and from the count process when the binary random variable has a value of 1 . In addition, we have included a inflation variable called organizational innovativeness, which measures the total number of patents registered by each firm over a four-year time period (log) (Bellamy et al., 2014). This inflation variable is used within the zero inflated negative binomial regression models to capture interfirm differences in the degree of organizational innovativeness. The Vuong test statistic also indicates that we should report the results from the negative binomial and zero-inflated negative 
binomial regression models to illustrate that our results remain consistent according to different econometric estimation models (Greene, 2011).

\subsection{Variable operationalisation}

Within the academic literature, patents represent one of the most widely used measures of inter-organizational innovation within different industries and countries (Kim and Song, 2007; Belderbos et al., 2014). As the context of our research is the development of interorganizational eco-innovations between Japanese automakers and their suppliers, we focus on patent data from the Japan Patent Office (JPO) and its Japan Platform for Patented Information (JPFI) database. The JPFI database has certain advantages as it contains accurate information about patents registered by firms in the Japanese automotive industry. We followed a systematic approach to our data collection procedures that utilized similar methods used by Kim and Song (2007), Borgstedt et al. (2017), and Rizzi et al (2014). We began by creating a patent database that recorded data about all the co-patents registered by Toyota and its suppliers over a four year time period. This patent database included accurate information on the patent publication number, date of publication of application, patent codes, application number, date of filing, patent diagrams, co-assignee names, inventor names, patent title, and the patent abstract.

Similar to past research by Borgstedt et al (2017), Oltra and Saint Jean (2009), Sick et al (2016), and van den Hoed (2005) we use relevant keywords to identify co-patents that focus on alternative fuel technologies. We use patent keyword searches as eco-innovations related to electric, hybrid, and hydrogen fuel cell technologies do not always correspond with International Patent Classification (IPC) codes and there can be overlaps between different closely related technological fields (Golembiewski et al 2015; Borgstedt et al., 2017). For example, some of the IPC codes can suffer from a lack of automotive usability, such as the IPC code that focuses on fuel cells (code: H01M-008) that contains many different technologies that do not relate to hydrogen fuel cells used within automotive vehicles (Borgstedt et al., 2017). Consequently, we use keyword searches to identify co-patents that focus on ecoinnovations in electric, hybrid, and hydrogen fuel cell technologies. We follow the delineation approach developed by Rizzi et al (2014) and Borgstedt et al (2017) that identifies whether a patent title and abstract include particular keywords that focus on alternative fuel cell technologies. Drawing upon Rizzi et al (2014), Golembiewski et al (2015) and Borgstedt et al (2017), we use keywords that are frequently found within patents for alternative fuel technologies, such as regenerative braking, batteries, electric motors, electric vehicles, hybrid 
engines, hybrid vehicles, and hydrogen fuel cell vehicles. Additionally, we also used a range of available secondary data sources to identify if the firm and Toyota are working on the development of inter-organizational eco-innovations, such as scientific papers, journals articles, industry reports, conference papers, the Bloomberg database, Marklines.com, and company websites. We then followed a similar data collection approach to develop our measures of supplier electric capabilities, supplier hybrid capabilities, and supplier fuel cell capabilities. More details about our measures can be found below.

Dependent variable: eco-innovation co-patenting: Previous studies by Oltra and Jean (2009), Berrone et al. (2013) and Borgstedt et al. (2017) have used patent statistics to measure the degree of eco-innovation. As we were interested in the involvement of suppliers in ecoinnovation, we focused on co-patents registered by Toyota and its suppliers over the past four years. We used detailed patent data from the Japan Platform for Patented Information (JPFI), which provides in-depth information on patents in the Japanese automotive industry and is managed and maintained by the Japanese Patent Office. These patent applications are those for which Toyota and one of its suppliers are registered as co-assignees on the co-patent document and were directly involved in the joint development of an eco-innovation that has been identified by the patent office as a novel or inventive innovation. We adapted Kim and Song's (2007) measure of co-patenting intensity by measuring eco-innovation co-patents between firm “ $i$ ” (e.g. Toyota Motor Corp) and firm “ $j ”$, in our case a firm from its supplier association during the last four years. We searched and read all the Toyota-supplier co-patents to identify the ecoinnovations that focused on regenerative braking, batteries, electric motors, electric vehicles, hybrid engines, hybrid vehicles, and hydrogen fuel cell vehicles. Following Borgstedt et al.'s (2017) research, we paid close attention to the patent title, abstract, keywords and patent class to determine whether a co-patent is an eco-innovation. Each of these patent abstracts and documents was then inspected to verify that the particular co-patent was related to an ecoinnovation that was jointly developed between Toyota and its suppliers. In total, we found 1,118 co-patents between Toyota and its suppliers that relate to eco-innovations in alternative fuel technologies during this four-year period.

Supplier electric capabilities: Research has shown that patent count data is a good measure of the innovation capabilities of a firm and its technological competitiveness in a particular technical field (Rizzi et al., 2014; Golembiewski et al., 2015; Borgstedt et al., 2017). Furthermore, research by Srivastava and Gnyawali (2011) and Xu et al. (2013) measure internal technological strength as a firm's patent count within a specific technological field. Within this study, we adapted previous measures of firm technological strength in specific innovation 
fields to develop our measures of supplier eco-innovation capabilities (Srivastava and Gnyawali, 2011; Xu et al., 2013; Golembiewski et al., 2015). Similar to research by Borgstedt et al. (2017), we used the database from the Japan Platform for Patented Information (JPFI) to measure the number of patents related to electric motor and electric vehicle technologies registered by each firm in the Toyota supplier association in a four-year time period. We searched and read the patent abstracts from each firm in the supplier association that contained terms relating to electric motors or electric vehicle technologies in the patent title or abstract, we then examined each patent to ensure that it did indeed relate to electric vehicle technology.

Supplier hybrid capabilities: We then adopted a similar approach to measure the extent to which firms had developed innovation capabilities in hybrid engine and hybrid vehicle technologies (Srivastava and Gnyawali 2011; Golembiewski et al., 2015; Borgstedt et al., 2017). To capture the degree of supplier hybrid capabilities, we measured the total number of patents each firm had registered in the hybrid engine and hybrid vehicle technological fields. Using the Japan Platform for Patented Information (JPFI) database from the Japanese Patent Office (JPO), we searched and read the patent titles and abstracts that each firm had developed over the same four-year time span to identify the total number of patents that focused on hybrid engine and hybrid vehicle technologies. Additionally, we used teardown reports from Marklines.com of the latest fourth generation Toyota Prius to confirm which components different firms produced for the hybrid engine and whether this technology had been patented as well.

Supplier fuel cell capabilities: Adapting Rizzi et al.'s (2014) measure of hydrogen fuel cell capabilities, we measured the total number of patents each firm had registered that related to hydrogen fuel cell technologies (Srivastava and Gnyawali, 2011; Xu et al., 2013). Based on past research using firm level patent data to measure the fuel cell capabilities of different organizations, we measured the total number of patents each firm in the supplier association had registered over a four-year period (Rizzi et al., 2014; Borgstedt et al., 2017). Using patent data from the Japan Platform for Patented Information (JPFI), we searched and read the patent titles and abstracts filled by each firm in the Toyota supplier association to determine the number of patents that focused on hydrogen fuel cell technology.

Alliance partner diversity: A large number of studies within the management literature have measured alliance partner diversity as the total number of strategic alliances each firm has with other organizations (Jiang et al., 2010; Terjesen et al., 2011; Popadic et al., 2016). In this paper, we measured the total number of strategic alliances of each firm in the Toyota supplier association with other organizations such as suppliers, automakers, and other firms in the 
automotive industry. Specifically, we used datasets from S\&P Capital IQ that identify the registered strategic alliances of each firm in the automotive industry with external organizations. This data was then compared with a range of secondary data sources to improve the validity of this measure, such as the Bloomberg database, company websites, industry reports, the AutomotiveNews.com database, and trade journals about strategic alliances in the automotive industry.

Control variables: A series of control variables were also included that can influence eco-innovation co-patenting, such as firm size, which measures the number of employees ( $\log )$, and firm age, which captures the number of years since the firm was established (log). Using data from Toyota (2016) that provides details of the products each firm in its supplier association provides to Toyota, we developed a measure called engine system, which identifies whether the firm produces components for vehicle engines, ranging from transmissions, pistons, and clutches to gears, camshafts, radiators, and engine belts. Furthermore, a measure was developed that focuses on whether the firm produces a module system for Toyota, such as a product system, module, assembly, or sub-assembly. To control for the effects of market competition, we used a dataset from automotivenews.com, which provides details of the major competitors that manufacture the same products produced by each firm in the Toyota supplier association (log). As the degree of technological turbulence varies between different industries, we used Jacobs et al.'s (2015) measure of fast clock speed industry, which captures whether the firm operates in a technologically turbulent industry such as IT, semiconductors, or computers. As R\&D activities are also likely to influence the degree of eco-innovation copatenting, we developed a variable called $R \& D$ centres that measures the number of $R \& D$ centres, technology centres, laboratories, development centres, and software centres owned by each firm in the supplier association (log). Finally, using data from S\&P Capital IQ and Compustat, we included two dichotomous variables that measure whether Toyota or one of its competitors has made a financial investment in each of the firms in the supplier association.

\section{Empirical findings}

\subsection{Results from the Toyota supplier association}

The results from the negative binomial regression models and zero-inflated negative binomial regression models are shown in Tables 2, 3, and 4, which depict the relationships for each of the main hypotheses in a sequential manner. Overall, we found strong support for 
hypothesis 1 in Model 2 of Table 2, which shows that firms with supplier electric capabilities are more likely to be co-patenting with Toyota on the development of eco-innovations $(\mathrm{p}<0.01)$. In addition, we also found that a positive relationship between supplier electric capabilities and eco-innovation co-patents occurs within the zero-inflated negative binomial model (see Model 6 in Table 2). Support was also found for hypothesis 2, as our empirical findings show that a significant positive relationship occurs between supplier hybrid capabilities and the occurrence of eco-innovation co-patenting, a result that is statistically significant at the ninety-nine percent level $(\mathrm{p}<0.01)$. Once again, a zero-inflated negative binomial regression model was used to test the robustness of this finding, which revealed a significant positive relationship between supplier hybrid capabilities and the degree of ecoinnovation co-patenting (see model 6 in Table 3). However, we did not observe significant support for the direct effect of supplier fuel cell capabilities on eco-innovation co-patenting in either the negative binomial model or the zero-inflated negative binomial model in Table 4, as shown in models 2 and 6 respectively ( $p=n . s)$.

\section{$<<$ Insert tables 2, 3 and 4 here $>>$}

By contrast, we found mixed results for the moderating effect of alliance partner diversity on the relationship between supplier eco-innovation capabilities and eco-innovation copatenting. According to hypothesis $4 \mathrm{a}$, we expected to find that alliance partner diversity would have a positive moderating effect on the relationship between supplier electric capabilities and eco-innovation co-patenting. Instead, we observed in model 4 of Table 2 that alliance partner diversity has a negative, rather than a positive, moderating effect that is statistically significant at the ninety-five percent level $(\mathrm{p}<0.05)$. In a similar manner, we found that alliance partner diversity has a negative moderating effect on the relationship between supplier hybrid capabilities and eco-innovation co-patenting, a result that is statistically significant at the ninety-nine percent level $(\mathrm{p}<0.01)$ (see in model 4 in Table 3$)$.

To explore these moderating effects in more detail, we developed simple slope statistics and interaction plots for low and high levels of alliance partner diversity. Regression equations were developed for each relationship at low (i.e. no alliance partners) and high levels of alliance partner diversity (i.e. five or more alliance partners). For hypothesis $4 \mathrm{a}$, when a firm has a high level of alliance partner diversity, we found no significant moderating effect on the relationship between supplier electric capabilities and eco-innovation co-patenting ( $\beta=1.25 ; p=n$.s.). By contrast, the simple slope statistics demonstrate that when firms do not have any alliance partners, a statistically significant moderating effect occurs $(\beta=2.09 ; p<0.01)$. To explore this in a more intuitive manner, we produced an interaction plot that depicts the nature of the 
moderating relationship at low and high levels of alliance partner diversity (Fig. 3.). This revealed that the significant positive relationship between supplier electric capabilities and ecoinnovation co-patenting occurs primarily when firms have no alliance partners. To unravel this finding, we also included an interaction slope for firms with only one alliance partner. A significant moderating effect emerged and produced a strong positive relationship between supplier electric capabilities and eco-innovation co-patenting with Toyota.

\section{$<<$ Insert Figures 3 and 4 here $>>$}

A similar pattern occurred when we explored the simple slope statistics and interaction plots for the moderating effect of alliance partner diversity on the relationship between supplier hybrid capabilities and eco-innovation co-patenting (i.e. hypothesis $4 \mathrm{~b}$ ). We found that when firms in the supplier association have a high level of alliance partner diversity, there is no statistically significant relationship between supplier hybrid capabilities and eco-innovation co-patenting with Toyota $(\beta=0.88 ; p=n . s$.$) . According to the simple slope statistics, when firms$ do not have any alliance partners, a highly significant moderating effect occurs and a positive relationship emerges between supplier hybrid capabilities and eco-innovation co-patenting $(\beta=1.81 ; \mathrm{p}<0.01)$. These findings are also illustrated in the interaction plot (Fig. 4), in which a clear positive relationship is evident between supplier hybrid capabilities and eco-innovation co-patenting when firms have no alliance partners but also when they only have one alliance partner with which they collaborate.

\subsection{Results from different Japanese automakers and their supplier networks}

We used firm level data from the Japan Auto Parts Industries Association (JAPIA, 2018), which is an industry association that provided an accurate list of the different automotive suppliers within Japan. We followed the same approach as we used for the Toyota supplier association to construct variables for the Honda, Daihatsu, Suzuki, Mitsubishi, and Nissan supplier networks. In particular, we only chose firms with supplier eco-innovation capabilities in electric, hybrid, and fuel cell patented technologies, as this is the focus of our study. Interestingly, we observed large variations in the rate of eco-innovation co-patenting between different Japanese automakers. Consequently, due to the lower rate of eco-innovation copatenting by some automakers we used multivariate logistic regression models. Within these models, the dependent variable measures whether the firm in the supplier network has registered an eco-innovation co-patent with a particular Japanese automaker (1=yes) or not 
$(0=$ no $)$ over the past four years. The logistic regression models are expressed as follows (Woolridge, 2013):

$$
P=\frac{p_{i}}{\left(1-p_{i}\right)}=b_{0}+b_{i} X_{i}+\cdots+b_{n} X_{n}
$$

In the models, $p_{i}$ is the probability of an eco-innovation co-patent between the firm and the automaker, $b_{i}$ is the coefficients, and $X_{i}$ represents the independent variables (Greene, 2011). The results from the logistic regression models are presented in Tables 5, 6, and 7 that show the $b$ coefficients, significance levels, and $\operatorname{Exp}(B)$ odds ratios. Overall, we find support for hypothesis 1 as the positive relationship between supplier electric capabilities and ecoinnovation co-patenting occurred within a number of supplier networks, especially for Honda $(\mathrm{p}<0.01)$, Daihatsu $(\mathrm{p}<0.05)$, and Suzuki $(\mathrm{p}<0.05)$ (see Models 1, 2, and 3 in Table 5). However, we only found support for hypothesis 2 within the Mitsubishi supplier network where supplier hybrid capabilities positively influenced eco-innovation co-patenting $(p<0.05)$ (see Model 4 in Table 6). One explanation for this finding is that Mitsubishi has developed with its suppliers a new High Range Series Parallel Hybrid engine that generates a better balance of electric efficiency and longer driving ranges (Ehsani et al., 2018). By comparison, no significant relationship exists between supplier hybrid capabilities and eco-innovation copatenting amongst the other Japanese automakers ( $\mathrm{p}=\mathrm{n}$.s.), which may reflect the maturing of the technology used within hybrid vehicles (Garcia et al., 2017). Although we did not find support for hypothesis 3 within the Toyota supplier association, we identified that supplier fuel cell capabilities is positively associated with eco-innovation co-patenting within the Honda supplier network $(\mathrm{p}<0.01)$, the Daihatsu supplier network $(\mathrm{p}<0.05)$, and the Suzuki supplier network $(\mathrm{p}<0.10)$ (see Models 1, 2, and 3 in Table 7). One potential explanation for this finding is that these automakers may rely on their suppliers' eco-innovation capabilities because they lack the internal R\&D expertise to develop fuel cell technologies (Menguc et al., 2014).

$$
<<\text { Insert tables 5, 6, and } 7 \text { here }>>
$$

Finally, we explored the moderating effect of alliance partner diversity within different Japanese supplier networks. The results in Model 1 in Table 5 show that alliance partner diversity negatively influences the relationship between supplier electric capabilities and ecoinnovation co-patenting within the Honda supplier network $(\mathrm{p}<0.05)$. It appears that firms within the Toyota and Honda supplier networks adopt similar approaches by maintaining a small number of strategic alliances that are used to co-develop electric vehicle technologies (Liker and Choi, 2004). By contrast, the moderating effect of alliance partner diversity on the 
relationship between supplier hybrid capabilities and eco-innovation co-patenting appeared to be confined to the Toyota supplier association. This may reflect the fact that Toyota has invested heavily in building collaborative relationships with its suppliers during the design and co-development of hybrid engine components, especially as it remains the largest manufacturer of hybrid vehicles in Japan (Toyota, 2016). Additionally, there is also some evidence that alliance partner diversity has a negative influence on the relationship between supplier fuel cell capabilities and eco-innovation co-patenting within the Daihatsu supplier network $(\mathrm{p}<0.10)$ and the Suzuki supplier networks $(\mathrm{p}<0.10)$ (see Models 2 and 3 in Table 7). In total, alliance partner diversity is found to have a negative moderating effect within the majority of supplier networks within the Japanese automotive industry, including the Toyota supplier association, the Honda supplier network, the Daihatsu supplier network, and the Suzuki supplier network. Paradoxically, supplier eco-innovation capabilities and alliance partner diversity are not found to have any significant effects within the Nissan supplier network. This may reflect Nissan's decision to break up its supplier association in the 2000s and restructure its long-term supplier relationships (Aoki and Lennerfors, 2013).

\section{Discussion}

\subsection{Theoretical implications}

Our findings contribute to the development of the NRBV as a theoretical perspective by providing support for some of its lesser explored propositions (Hart and Dowell, 2011). According to the NRBV and eco-innovation literatures, firms can develop a sustainable competitive advantage through their ability to work collaboratively with their suppliers to generate a strong pipeline of inter-organizational eco-innovations (Roscoe et al., 2016). Our results found that supplier electric capabilities are positively associated with the occurrence eco-innovation co-patents with Toyota, Honda, Daihatsu, and Suzuki. Similar research has also shown that automakers are investing heavily in electric vehicle technology, with many working collaboratively with their suppliers to generate inter-organizational eco-innovations (Borgstedt et al., 2017). In a similar manner, Japanese automakers such as Toyota and Mitsubishi have 
also been the market leaders in hybrid engine technology and this is also reflected by the positive relationship between supplier hybrid capabilities and inter-organizational ecoinnovations (Christensen, 2011).

However, we did not find support for hypothesis 3 within the Toyota supplier association, as supplier fuel cell capabilities are not found to be significantly related to eco-innovation copatenting. A number of studies have suggested that there can be trade-offs when firms develop radical innovations that encourage them to develop in-house the key components within the fuel cell system (Hellman and Hoed, 2007; Menguc et al., 2014). Moreover, managers within Toyota may have chosen to limit the amount of supplier involvement due to the concern that its trade secrets will leak to competitors that are also trying to develop fuel cell technologies. For instance, we identify that supplier fuel cell capabilities have a positive effect on ecoinnovation co-patenting within the Honda, Daihatsu, and Suzuki supplier networks, especially as these automakers have also launched hydrogen fuel cell vehicles.

Building on the strategic alliance literature, we expected to find that alliance partner diversity would have a positive moderating effect on the relationship between supplier ecoinnovation capabilities and co-patenting (Jiang et al., 2010; Popadic et al., 2016). Instead, we identified mixed results, with alliance partner diversity having a negative rather than a positive moderating effect on the relationships between supplier electric and hybrid capabilities and eco-innovation co-patenting with Toyota. In a similar manner, alliance partner diversity was also found to have a negative moderating effect on the relationship between supplier electric capabilities and eco-innovation co-patenting within the Honda supplier network. We also identified some evidence that a portfolio of strategic alliances has a negative moderating effect on the relationship between supplier fuel cell capabilities and eco-innovation co-patenting with Daihatsu and Suzuki as well. In accordance with recent debates within the strategic alliance literature, this indicates that Japanese automakers and their suppliers may be less effective at managing a complex portfolio of alliance partners during the development of interorganizational eco-innovations (Cui and O'Connor, 2012; Leeuw et al. 2014). Our further analysis suggests that Toyota uses bilateral one-to-one strategic alliances to maintain strong ties to its strategic suppliers and loose weak ties to specialist suppliers with advanced ecoinnovation capabilities (Dyer and Nobeoka, 2000; Roscoe et al., 2016). This finding supports recent research by Roscoe et al (2016) that highlights how dyadic one-to-one strategic alliances between automakers and their suppliers play an important role by facilitating the development of inter-organization eco-innovations within supplier networks. 


\subsection{Managerial implications}

During the last decade, the business, scientific and policy communities have emphasized the important contribution that alternative fuel technologies can play in reducing $\mathrm{CO}_{2}$ and $\mathrm{NO}_{\mathrm{x}}$ emissions from vehicles. This becomes a difficult task for decision-makers, as many firms work with multiple suppliers that have a variety of different innovation capabilities in a range of technological fields. Our findings reveal that managers need to benchmark the innovation capabilities of different suppliers in electric, hybrid, and fuel cell technologies and then develop a strategic approach to developing alliances with these supply chain partners. In particular, we find that deep buyer-supplier alliances with a small number of suppliers may be an effective way to facilitate the co-development of electric, hybrid, and fuel cell technologies. However, we find that firms may be struggling to facilitate inter-organizational eco-innovation when they maintain a large portfolio of strategic alliances. One way to overcome this problem could be to create an Office of Alliance Management that helps to manage different strategic alliances across the supplier network (Rothaermel and Deeds, 2006).

\subsection{Research limitations and future research directions}

There are a number of important limitations associated with using patent data to measure inter-organizational eco-innovation within the Japanese automotive industry. One of the key limitations of this study is that we focused only on the Toyota supplier association and the supplier networks of different automakers within the Japanese automotive industry, which limits the generalisability of our findings to other automakers, supplier networks, industries, and countries. Another concern is that due to data limitations, we were unable to incorporate longitudinal trends into our data analysis. Moreover, patent data mainly focuses on innovations, with little consideration of the many incremental improvements that automakers and suppliers make to increasing environmental performance. Additionally, firms may choose not to register patents for their core trade secrets and technological inventions out of fear that competitors will use them to reverse engineer their new products.

However, our study only investigates the contributions that supplier electric capabilities, supplier hybrid capabilities, and supplier fuel cell capabilities make to eco-innovation copatenting, together with the moderating effect of alliance partner diversity. In reality, the development of any inter-organizational eco-innovation is a complex process that is affected by a number of parameters and contingent factors that are beyond the scope of our study. Consequently, there is a risk of over simplifying the complex process of developing ecoinnovations at the interface between automakers and the firms across their supplier network. In 
particular, by using patent data to explore inter-organizational eco-innovations we were unable to include case studies and gray scales to develop a richer understanding of the determinants of inter-firm collaboration during the development of green technologies. Finally, as many firms in the automotive industry use global sourcing by purchasing materials and components from international suppliers there is likely to be some overlap in the development of interorganizational eco-innovations between different automakers and their suppliers.

This study also raises a number of important avenues for future research to explore. First, future research could explore the co-patents that automakers have developed with their suppliers to improve the efficiency of the internal combustion engine so that it produces fewer emissions of $\mathrm{CO}_{2}, \mathrm{NO}_{x}$, and other pollutants that are harmful to human health and the environment. Second, it is also important that research explores how to manage the trade-offs associated with using strategic alliances to govern the joint development of eco-innovations. Finally, additional research could be undertaken into how automakers could work with their downstream customers, such as the roll out of electric vehicle charging stations and the development of hydrogen fuel infrastructure (Maase et al., 2018).

\section{Conclusions}

Building on the NRBV, eco-innovation, and supplier involvement literatures, our results suggest that supplier eco-innovation capabilities and alliance partner diversity can influence the development of inter-organizational eco-innovations. We contribute to the eco-innovation literature by undertaking one of the first empirical studies of the determinants of interorganizational eco-innovation when suppliers are involved in NPD. Using the research context of the Toyota supplier association, our empirical analysis reveals that supplier electric capabilities and hybrid capabilities are associated with a significant increase in the degree of eco-innovation co-patenting. However, we find mixed results for the extent to which alliance partner diversity moderates the relationship between supplier eco-innovation capabilities and co-patenting. Finally, we have also identified some of the similarities and differences between Japanese automakers in how they develop inter-organizational eco-innovations within their supplier networks. 


\section{References}

Aoki, K., Lennerfors, T., 2013. The new, improved keiretsu. Harvard. Bus. Rev. 91, 109-115. Aloise, P., Macke, J., 2017. Eco-innovations in developing countries: The case of Manaus Free Trade Zone. J. Clean. Prod. 168, 30-38.

Belderbos, R., Cassiman, B., Faems, D., Leten, B., Van Looy, B., 2014. Co-ownership of intellectual property: Exploring the value-appropriation and value-creation implications of co-patenting with different partners. Res. Policy. 43, 841-852.

Bellamy, M., Ghosh, S., Hora, M., 2014. The influence of supply network structure on firm innovation. J. Oper. Manag. 32, 357-373.

Berrone, P., Fosfuri, A., Gelabert, L., Gomez-Mejia, L., 2013. Necessity as the mother of green inventions: Institutional pressures and environmental innovations. Strategic Manag. J. 34, 891-909.

Borgstedt, P., Neyer, B., Schewe, G., 2017. Paving the road to electric vehicles - A patent analysis of the automotive industry. J. Clean. Prod. 167, 75-87.

Carrillo-Hermosilla, J., Rio, P., Könnölä, T. 2010. Diversity of eco-innovations: Reflections from selected case studies. J. Clean. Prod. 18, 1073-1083.

Cameron, A., Trivedi, P. 2010. Microeconometrics using STATA, STATA Press. College Station. Texas.

Chan, C. 2007. The State of the Art of Electric, Hybrid, and Fuel Cell Vehicles. Proceedings of the IEEE, 95, 704-718.

Christensen, T., 2011. Modularised eco-innovation in the auto industry. J. Clean. Prod. 19, 212220.

Cui, A., O’Connor, G. 2012. Alliance Portfolio Resource Diversity and Firm Innovation. J. of Marketing. 76, $24-43$.

Denyer, D., Tranfield, D., 2009. Producing a Systematic Review. The Sage Handbook of Organizational Research Methods. Sage Publications Ltd, Thousand Oaks, CA.

Dyer, J., Nobeoka, K., 2000. Creating and managing a high performance knowledge sharing network: The Toyota case. Strategic Manag. J. 21, 345-367.

Dyer, J., Singh, H., 1998. The relational view: Cooperative strategy and sources of interorganizational competitive advantage. Acad. Manag. Rev. 23, 660-679.

Ehsani, M., Gao,Y., Longo,S., Ebrahimi, K. 2018. Modern electric, hybrid electric, and fuel cell vehicles (third edition), Boca Raton, CRC Press.

Garcia, J., Millet, D., Tonnelier, P., Richet, S., Chenouard, R., 2017. A novel approach for global environmental performance evaluation of electric batteries for hybrid vehicles. J. Clean. Prod. 156, 406-417.

Golembiewski, B., Stein, N., Sick, N., Wiemhofer, H., 2015. Identifying trends in battery technologies with regard to electric mobility: evidence from patenting activities along and across the battery value chain. J. Clean. Prod. 87, 800-810.

Greene, W., 2011. Econometric Analysis. Pearson. New York.

Gunther, H., Kannegiesser, M., Autenrieb, N., 2015. The role of electric vehicles for supply chain sustainability in the automotive industry. J. Clean. Prod. 90, 220-233.

Hall, J., Kerr, R. 2003. Innovation dynamics and environmental technologies: the emergence of fuel cell technology. J. Clean. Prod. 11. 459-471.

Hart, S., Dowell, G., 2011. A natural-resource-based view of the firm: fifteen years after. J. Manag. 37, 1464-1479.

Hellman, H., Hoed, R. 2007. Characterising fuel cell technology: Challenges of the commercialisation process. Int. J. of Hydrogen Energy. 32, 305-315.

Hoed, R. 2005. Commitment to fuel cell technology: How to interpret carmakers' efforts in this radical technology, J. of Power Sources. 141, 265-271. 
Hoed, R. 2007. Sources of radical technological innovation: the emergence of fuel cell technology in the automotive industry. J. Clean. Prod. 15. 1014-1021.

Hult, G. T., Hurley, R., Knight, G., 2004. Innovativeness: Its antecedents and impact on business performance. Ind. Market. Manag. 33, 429-438.

Jacobs, M., Yu, W., Chavez, R., Fynes, B., Wiengarten, F., Lecuna, A., 2015. Internal lean practices and performance: The role of technological turbulence. Int. J. Prod. Econ. 160, $157-171$.

JAPIA (2018) Japan Auto Parts Industries Association. Available from: http://www.japia.or.jp/ [Last Accessed $25^{\text {th }}$ June 2018].

Jiang, R., Tao, Q., Santoro, M., 2010. Alliance portfolio diversity and firm performance. S. Manag. J. 31, 1136-1144.

Kim, C., Song, J., 2007. Creating new technology through alliances: An empirical investigation of joint patents. Technov. 27, 461-470.

Lawson, B., Tyler, B., Potter, A., 2015. Strategic suppliers' technical contributions to new product advantage: Substitution and configuration options. J. Prod. Innov. Manag. 32, 760-776.

Lee, C., Lim, J., Fan, Y., Liu, X., Fujiwara, T., Klemeš, J., 2018. Enabling low-carbon emissions for sustainable development in Asia and beyond. J. Clean. Prod. 176, 726-735.

Leeuw, T., Lokshin, B., Duysters, G. 2014. Returns to alliance portfolio diversity: The relative effects of partner diversity on firm's innovative performance and productivity. J. of Bus. Research. 67, 1839-1849.

Liker, J., Choi, T., 2004. Building deep supplier relationships. Harvard Bus. Rev. December, $1-11$.

MacDonald, E., She, J., 2015. Seven cognitive concepts for eco-design. J. Clean. Prod. 92, 2336.

Maase, S., Dilrosun, X., Kooi, M., Hoed, R. 2018. Performance of Electric Vehicle Charging Infrastructure: Development of an Assessment Platform Based on Charging Data. World Electric Vehicle J. 9, 1-17.

Menguc, B., Auh, S., and Yannopoulos, P. 2014. Customer and supplier involvement in design: The moderating role of incremental and radical innovation capability. J. of Prod. Innov. Manage. 31. 313-328.

Nanaki, E., Koroneos, C. 2013. Comparative economic and environmental analysis of conventional hybrid and electric vehicles - the case study of Greece. J. Clean. Prod. 53, 261-266.

Oltra, V., Jean, M., 2009. Variety of technological trajectories in low emission vehicles (LEVs): A patent data analysis. J. Clean. Prod. 17, 201-213.

Pacheco, D., Caten. C., Jung, C., Ribeiro, J., Navas, H., Cruz-Machado, V. 2017. Eco innovation determinants in manufacturing SMEs: Systematic review and research directionsJ. Clean. Prod. 142. 2277-2287.

Popadic, M., Pucko, D., Cerne, M., 2016. Exploratory innovation, exploitative innovation and innovation performance: The moderating role of alliance partner diversity. Econ. Bus. Rev. 18, 295-318.

Rizzi, F., Annunziata, E., Liberati, G., Frey, M., 2014. Technological trajectories in the automotive industry: are hydrogen technologies still a possibility? J. Clean. Prod. 66, 328-396.

Roscoe, S., Cousins, P., Lamming, R., 2016. Developing eco-innovations: a three-stage typology of supply networks. J. Clean. Prod. 112, 1948-1999.

Rothaermel, F. and Deeds, D. 2006. Alliance type, alliance experience and alliance management capability in high-technology ventures. J. of Bus. Venturing. 21. 429-460. 
Sampson, R. 2007. R\&D alliances and firm performance: The impact of technological diversity and alliance organization on innovation. Acad. Manage. J. 50, 364-386.

Sick, N., Nienaber, A., Liesekotter, B., Stein, N., Schewe, G., Leker, J. 2016. The legend about sailing ship effects - Is it true or false? The example of cleaner propulsion technologies diffusion in the automotive industry. J. Clean. Prod. 137, 405-413.

Srivastava, M., Gnyawali, D. 2011. When do relational resources matter? Leveraging portfolio technological resources for breakthrough innovation. Acad. of Manage. J. 54, 797-810.

Terjesen, S., Patel, P., Covin, J., 2011. Alliance diversity, environmental context and the value of manufacturing capabilities among new high technology ventures. J. Oper. Manag. 29, 105-115.

Toyota., 2016. Seventy-five years of Toyota: Production Engineering, Logistics and Purchasing. Toyota Motor, Japan.

Wilhelm, M., Kohlbacher, F., 2011. Co-opetition and knowledge co-creation in Japanese supplier-networks: The case of Toyota. Asian Bus. Manag. 10, 66-86.

Woolridge, J., 2013. Introductory Econometrics: A Modern Approach. Boston, Cengage.

Xavier, A., Naveiro, R., Aoussat, A., Reyes, T., 2017. Systematic literature review of ecoinnovation models: Opportunities and recommendations for future research. J. Clean. Prod. 149, 1278-1302.

$\mathrm{Xu}, \mathrm{S} ., \mathrm{Wu}, \mathrm{F}$. , Cavusgil, E., 2013. Complements or substitutes? Internal technological strength, competitor alliance participation, and innovation development. Journal of Prod. Innov. Manage. 30, 750-762.

Zapata, C., Nieuwenhuis, P., 2010. Exploring innovation the automotive industry: new technologies for cleaner cars. J. Clean. Prod. 18, 14-20.

\section{Acknowledgements}

We would like to thank our universities for providing the funding and resources for this research project that explores recent changes in the management practices, supply chain and innovation activities of firms in the Japanese automotive industry. Funding was provided for access to the research databases used in this paper. Declarations of interest: none. 
Table 1

\section{Correlation matrix}

\begin{tabular}{|c|c|c|c|c|c|c|c|c|c|c|c|c|}
\hline Variables & (1) & (2) & (3) & (4) & (5) & (6) & (7) & (8) & (9) & (10) & (11) & $(12)$ \\
\hline Firm size & 1.00 & & & & & & & & & & & \\
\hline Firm age & $\begin{array}{l}0.07 \\
(0.39)\end{array}$ & 1.00 & & & & & & & & & & \\
\hline Engine system & $\begin{array}{l}-0.08 \\
(0.34)\end{array}$ & $\begin{array}{l}0.14^{*} \\
(0.09)\end{array}$ & 1.00 & & & & & & & & & \\
\hline Module system & $\begin{array}{l}0.15^{*} \\
(0.08)\end{array}$ & $\begin{array}{l}0.05 \\
(0.59)\end{array}$ & $\begin{array}{l}-0.13 \\
(0.14)\end{array}$ & 1.00 & & & & & & & & \\
\hline Market competition & $\begin{array}{l}0.09 \\
(0.28)\end{array}$ & $\begin{array}{l}0.10 \\
(0.22)\end{array}$ & $\begin{array}{l}0.12 \\
(0.15)\end{array}$ & $\begin{array}{l}0.17^{* *} \\
(0.04)\end{array}$ & 1.00 & & & & & & & \\
\hline Fast clock speed industry & $\begin{array}{l}0.11 \\
(0.18)\end{array}$ & $\begin{array}{l}0.09 \\
(0.28)\end{array}$ & $\begin{array}{l}0.08 \\
(0.35)\end{array}$ & $\begin{array}{l}0.14^{*} \\
(0.09)\end{array}$ & $\begin{array}{l}0.17^{* *} \\
(0.04)\end{array}$ & 1.00 & & & & & & \\
\hline$R \& D$ centres & $\begin{array}{l}0.05 \\
(0.53)\end{array}$ & $\begin{array}{l}0.06 \\
(0.47)\end{array}$ & $\begin{array}{l}-0.05 \\
(0.56)\end{array}$ & $\begin{array}{l}0.14 \\
(0.11)\end{array}$ & $\begin{array}{l}0.06 \\
(0.47)\end{array}$ & $\begin{array}{l}0.11 \\
(0.19)\end{array}$ & 1.00 & & & & & \\
\hline Toyota investment & $\begin{array}{l}0.14 \\
(0.11)\end{array}$ & $\begin{array}{l}-0.04 \\
(0.62)\end{array}$ & $\begin{array}{l}-0.00 \\
(0.99)\end{array}$ & $\begin{array}{l}0.11 \\
(0.21)\end{array}$ & $\begin{array}{l}0.26 * * * \\
(0.00)\end{array}$ & $\begin{array}{l}0.05 \\
(0.59)\end{array}$ & $\begin{array}{l}0.04 \\
(0.62)\end{array}$ & 1.00 & & & & \\
\hline Competitor investment & $\begin{array}{l}0.37 * * * \\
(0.00)\end{array}$ & $\begin{array}{l}-0.01 \\
(0.90)\end{array}$ & $\begin{array}{l}-0.14^{*} \\
(0.09)\end{array}$ & $\begin{array}{l}-0.05 \\
(0.52)\end{array}$ & $\begin{array}{l}0.01 \\
(0.92)\end{array}$ & $\begin{array}{l}-0.01 \\
(0.87)\end{array}$ & $\begin{array}{l}0.16^{*} \\
(0.06)\end{array}$ & $\begin{array}{l}-0.07 \\
(0.40)\end{array}$ & 1.00 & & & \\
\hline Supplier electric capabilities & $\begin{array}{l}0.34 * * * \\
(0.00)\end{array}$ & $\begin{array}{l}0.05 \\
(0.59)\end{array}$ & $\begin{array}{l}-0.06 \\
(0.46)\end{array}$ & $\begin{array}{l}0.33^{* * * *} \\
(0.00)\end{array}$ & $\begin{array}{l}0.16^{*} \\
(0.06)\end{array}$ & $\begin{array}{l}0.23 * * * \\
(0.01)\end{array}$ & $\begin{array}{l}0.25 * * * \\
(0.00)\end{array}$ & $\begin{array}{l}-0.03 \\
(0.73)\end{array}$ & $\begin{array}{l}0.34 * * * \\
(0.00)\end{array}$ & 1.00 & & \\
\hline Supplier hybrid capabilities & $\begin{array}{l}0.19 * * \\
(0.03)\end{array}$ & $\begin{array}{l}-0.02 \\
(0.80)\end{array}$ & $\begin{array}{l}0.08 \\
(0.34)\end{array}$ & $\begin{array}{l}0.04 \\
(0.62)\end{array}$ & $\begin{array}{l}0.03 \\
(0.73)\end{array}$ & $\begin{array}{l}-0.04 \\
(0.65)\end{array}$ & $\begin{array}{l}0.21 * * * \\
(0.01)\end{array}$ & $\begin{array}{l}0.08 \\
(0.36)\end{array}$ & $\begin{array}{l}0.24 * * * \\
(0.00)\end{array}$ & $\begin{array}{l}0.59 * * * \\
(0.00)\end{array}$ & 1.00 & \\
\hline Supplier fuel cell capabilities & $\begin{array}{l}0.27 * * * \\
(0.00)\end{array}$ & $\begin{array}{l}0.09 \\
(0.29)\end{array}$ & $\begin{array}{l}-0.06 \\
(0.51)\end{array}$ & $\begin{array}{l}0.13 \\
(0.12)\end{array}$ & $\begin{array}{l}0.05 \\
(0.57)\end{array}$ & $\begin{array}{l}0.04 \\
(0.65)\end{array}$ & $\begin{array}{l}0.11 \\
(0.17)\end{array}$ & $\begin{array}{l}-0.13 \\
(0.13)\end{array}$ & $\begin{array}{l}0.25 * * * \\
(0.00)\end{array}$ & $\begin{array}{l}0.60 * * * \\
(0.00)\end{array}$ & $\begin{array}{l}0.22 * * \\
(0.01)\end{array}$ & 1.00 \\
\hline
\end{tabular}

Note: Multicollinearity is not a concern within these models, as the Variance Inflation Factor (VIF) scores fall below the threshold value for each of the variables in the models. 
Table 2

The relationship between supplier electric capabilities and eco-innovation co-patenting

\begin{tabular}{|c|c|c|c|c|c|c|c|c|}
\hline & $\begin{array}{c}\text { Model } 1 \\
\text { (NB) }\end{array}$ & $\begin{array}{c}\text { Model } 2 \\
\text { (NB) }\end{array}$ & $\begin{array}{c}\text { Model } 3 \\
\text { (NB) }\end{array}$ & $\begin{array}{c}\text { Model } 4 \\
\text { (NB) }\end{array}$ & $\begin{array}{c}\text { Model } 5 \\
\text { (ZINB) }\end{array}$ & $\begin{array}{c}\text { Model } 6 \\
\text { (ZINB) }\end{array}$ & $\begin{array}{c}\text { Model } 7 \\
\text { (ZINB) }\end{array}$ & $\begin{array}{c}\text { Model } 8 \\
\text { (ZINB) }\end{array}$ \\
\hline \multicolumn{9}{|l|}{ Control variables: } \\
\hline Firm size & $\begin{array}{l}0.38 \\
(0.22)\end{array}$ & $\begin{array}{l}0.74 * * \\
(0.02)\end{array}$ & $\begin{array}{l}0.69^{* *} \\
(0.04)\end{array}$ & $\begin{array}{l}0.56 \\
(0.12)\end{array}$ & $\begin{array}{l}-0.10 \\
(0.65)\end{array}$ & $\begin{array}{l}0.26 \\
(0.35)\end{array}$ & $\begin{array}{l}0.27 \\
(0.36)\end{array}$ & $\begin{array}{l}0.17 \\
(0.55)\end{array}$ \\
\hline Firm age & $\begin{array}{l}-0.63 \\
(0.16)\end{array}$ & $\begin{array}{l}-0.27 \\
(0.45)\end{array}$ & $\begin{array}{l}-0.29 \\
(0.42)\end{array}$ & $\begin{array}{l}-0.27 \\
(0.41)\end{array}$ & $\begin{array}{l}-0.57^{*} \\
(0.10)\end{array}$ & $\begin{array}{l}-0.21 \\
(0.57)\end{array}$ & $\begin{array}{l}-0.21 \\
(0.58)\end{array}$ & $\begin{array}{l}-0.24 \\
(0.45)\end{array}$ \\
\hline Engine system & $\begin{array}{l}0.39 \\
(0.24)\end{array}$ & $\begin{array}{l}0.23 \\
(0.44)\end{array}$ & $\begin{array}{l}0.27 \\
(0.40)\end{array}$ & $\begin{array}{l}0.07 \\
(0.82)\end{array}$ & $\begin{array}{l}0.66^{* *} \\
(0.04)\end{array}$ & $\begin{array}{l}0.64 * \\
(0.06)\end{array}$ & $\begin{array}{l}0.63^{*} \\
(0.07)\end{array}$ & $\begin{array}{l}0.40 \\
(0.25)\end{array}$ \\
\hline Module system & $\begin{array}{l}-0.20 \\
(0.45)\end{array}$ & $\begin{array}{l}-0.38^{*} \\
(0.09)\end{array}$ & $\begin{array}{l}-0.38^{*} \\
(0.10)\end{array}$ & $\begin{array}{l}-0.44^{* *} \\
(0.05)\end{array}$ & $\begin{array}{l}-0.27 \\
(0.12)\end{array}$ & $\begin{array}{l}-0.43 * * * \\
(0.01)\end{array}$ & $\begin{array}{l}-0.44 * * \\
(0.02)\end{array}$ & $\begin{array}{l}-0.47^{* * *} \\
(0.00)\end{array}$ \\
\hline Market competition & $\begin{array}{l}-0.25 \\
(0.46)\end{array}$ & $\begin{array}{l}-0.66^{* *} \\
(0.05)\end{array}$ & $\begin{array}{l}-0.68^{* *} \\
(0.05)\end{array}$ & $\begin{array}{l}-0.58^{*} \\
(0.07)\end{array}$ & $\begin{array}{l}-0.09 \\
(0.76)\end{array}$ & $\begin{array}{l}-0.74 * * \\
(0.02)\end{array}$ & $\begin{array}{l}-0.74 * * \\
(0.03)\end{array}$ & $\begin{array}{l}-0.45 \\
(0.23)\end{array}$ \\
\hline Fast clock speed industry & $\begin{array}{l}-0.39 \\
(0.17)\end{array}$ & $\begin{array}{l}-0.41 \\
(0.11)\end{array}$ & $\begin{array}{l}-0.42^{*} \\
(0.10)\end{array}$ & $\begin{array}{l}-0.46^{*} \\
(0.07)\end{array}$ & $\begin{array}{l}-0.29 \\
(0.23)\end{array}$ & $\begin{array}{l}-0.35 \\
(0.13)\end{array}$ & $\begin{array}{l}-0.35 \\
(0.13)\end{array}$ & $\begin{array}{l}-0.40^{*} \\
(0.08)\end{array}$ \\
\hline R\&D centres & $\begin{array}{l}0.44^{*} \\
(0.08)\end{array}$ & $\begin{array}{l}0.31 \\
(0.15)\end{array}$ & $\begin{array}{l}0.30 \\
(0.17)\end{array}$ & $\begin{array}{l}0.26 \\
(0.22)\end{array}$ & $\begin{array}{l}0.51 * * * \\
(0.01)\end{array}$ & $\begin{array}{l}0.34 * \\
(0.09)\end{array}$ & $\begin{array}{l}0.35^{*} \\
(0.09)\end{array}$ & $\begin{array}{l}0.38^{*} \\
(0.06)\end{array}$ \\
\hline Toyota investment & $\begin{array}{l}0.54 \\
(0.11)\end{array}$ & $\begin{array}{l}0.74 * * \\
(0.02)\end{array}$ & $\begin{array}{l}0.76^{* *} \\
(0.02)\end{array}$ & $\begin{array}{l}0.70^{* *} \\
(0.02)\end{array}$ & $\begin{array}{l}0.49^{*} \\
(0.07)\end{array}$ & $\begin{array}{l}0.90 * * * \\
(0.01)\end{array}$ & $\begin{array}{l}0.90^{* * * *} \\
(0.01)\end{array}$ & $\begin{array}{l}0.66^{* *} \\
(0.05)\end{array}$ \\
\hline Competitor investment & $\begin{array}{l}0.49 * \\
(0.07)\end{array}$ & $\begin{array}{l}-0.48^{*} \\
(0.10)\end{array}$ & $\begin{array}{l}-0.50^{*} \\
(0.10)\end{array}$ & $\begin{array}{l}-0.51^{*} \\
(0.08)\end{array}$ & $\begin{array}{l}0.55 * * * \\
(0.01)\end{array}$ & $\begin{array}{l}-0.23 \\
(0.43)\end{array}$ & $\begin{array}{l}-0.23 \\
(0.45)\end{array}$ & $\begin{array}{l}-0.18 \\
(0.56)\end{array}$ \\
\hline \multicolumn{9}{|l|}{ Explanatory variable: } \\
\hline Supplier electric capabilities & - & $\begin{array}{l}1.03 * * * \\
(0.00)\end{array}$ & $\begin{array}{l}0.99 * * * \\
(0.00)\end{array}$ & $\begin{array}{l}1.80 * * * \\
(0.00)\end{array}$ & - & $\begin{array}{l}0.74 * * * \\
(0.00)\end{array}$ & $\begin{array}{l}0.74 * * * \\
(0.00)\end{array}$ & $\begin{array}{l}1.19 * * * \\
(0.00)\end{array}$ \\
\hline \multicolumn{9}{|l|}{ Moderator variable: } \\
\hline Alliance partner diversity & - & - & $\begin{array}{l}0.14 \\
(0.73)\end{array}$ & $\begin{array}{l}0.24 \\
(0.57)\end{array}$ & - & - & $\begin{array}{l}-0.02 \\
(0.96)\end{array}$ & $\begin{array}{l}0.05 \\
(0.87)\end{array}$ \\
\hline $\begin{array}{l}\text { Interaction effects: } \\
\text { Supplier electric capabilities } \\
\text { X alliance partner diversity }\end{array}$ & - & - & - & $\begin{array}{l}-0.42 * * \\
(0.03)\end{array}$ & - & - & - & $\begin{array}{l}-0.26^{* *} \\
(0.03)\end{array}$ \\
\hline Log likelihood statistic & -264.91 & -257.12 & -257.07 & -255.33 & -256.71 & -251.58 & -251.58 & -249.91 \\
\hline LR chi-square statistic & $22.32 * * *$ & $37.88 * * *$ & $38.00 * * *$ & $41.46^{* * *}$ & $29.91 * * *$ & $40.18 * * *$ & $40.18 * * *$ & $43.52 * * *$ \\
\hline Vuong test statistic & - & - & - & - & $1.66 * *$ & $1.30 *$ & $1.27 *$ & 1.16 \\
\hline Vuong test ( $p$ value) & - & - & - & - & $(0.05)$ & $(0.10)$ & $(0.10)$ & $(0.12)$ \\
\hline $\mathrm{N}$ & 143 & 143 & 143 & 143 & 143 & 143 & 143 & 143 \\
\hline
\end{tabular}

NB: Negative binomial regression models; ZINB: Zero-inflated negative binomial regression models 
Table 3

The relationship between supplier hybrid capabilities and eco-innovation co-patenting

\begin{tabular}{|c|c|c|c|c|c|c|c|c|}
\hline & $\begin{array}{c}\text { Model } 1 \\
(\mathrm{NB})\end{array}$ & $\begin{array}{c}\text { Model } 2 \\
(\mathrm{NB})\end{array}$ & $\begin{array}{c}\text { Model } 3 \\
\text { (NB) }\end{array}$ & $\begin{array}{c}\text { Model } 4 \\
(\mathrm{NB})\end{array}$ & $\begin{array}{c}\text { Model } 5 \\
\text { (ZINB) }\end{array}$ & $\begin{array}{c}\text { Model } 6 \\
\text { (ZINB) }\end{array}$ & $\begin{array}{c}\text { Model } 7 \\
\text { (ZINB) }\end{array}$ & $\begin{array}{c}\text { Model } 8 \\
\text { (ZINB) }\end{array}$ \\
\hline \multicolumn{9}{|l|}{ Control variables: } \\
\hline Firm size & $\begin{array}{l}0.38 \\
(0.22)\end{array}$ & $\begin{array}{l}0.76^{* *} \\
(0.02)\end{array}$ & $\begin{array}{l}0.65^{*} \\
(0.06)\end{array}$ & $\begin{array}{l}0.55^{*} \\
(0.09)\end{array}$ & $\begin{array}{l}-0.10 \\
(0.65)\end{array}$ & $\begin{array}{l}0.44 \\
(0.16)\end{array}$ & $\begin{array}{l}0.44 \\
(0.16)\end{array}$ & $\begin{array}{l}0.21 \\
(0.43)\end{array}$ \\
\hline Firm age & $\begin{array}{l}-0.63 \\
(0.16)\end{array}$ & $\begin{array}{l}-0.12 \\
(0.68)\end{array}$ & $\begin{array}{l}-0.17 \\
(0.58)\end{array}$ & $\begin{array}{l}-0.25 \\
(0.41)\end{array}$ & $\begin{array}{l}-0.57^{*} \\
(0.10)\end{array}$ & $\begin{array}{l}-0.20 \\
(0.51)\end{array}$ & $\begin{array}{l}-0.20 \\
(0.52)\end{array}$ & $\begin{array}{l}-0.40 \\
(0.20)\end{array}$ \\
\hline Engine system & $\begin{array}{l}0.39 \\
(0.24)\end{array}$ & $\begin{array}{l}-0.87 * * \\
(0.02)\end{array}$ & $\begin{array}{l}-0.84 * * \\
(0.03)\end{array}$ & $\begin{array}{l}-1.03 * * * \\
(0.01)\end{array}$ & $\begin{array}{l}0.66^{* *} \\
(0.04)\end{array}$ & $\begin{array}{l}-0.51 \\
(0.19)\end{array}$ & $\begin{array}{l}-0.51 \\
(0.19)\end{array}$ & $\begin{array}{l}-0.75^{* *} \\
(0.02)\end{array}$ \\
\hline Module system & $\begin{array}{l}-0.20 \\
(0.45)\end{array}$ & $\begin{array}{l}-0.18 \\
(0.41)\end{array}$ & $\begin{array}{l}-0.14 \\
(0.54)\end{array}$ & $\begin{array}{l}-0.11 \\
(0.61)\end{array}$ & $\begin{array}{l}-0.27 \\
(0.12)\end{array}$ & $\begin{array}{l}-0.19 \\
(0.31)\end{array}$ & $\begin{array}{l}-0.20 \\
(0.31)\end{array}$ & $\begin{array}{l}-0.15 \\
(0.40)\end{array}$ \\
\hline Market competition & $\begin{array}{l}-0.25 \\
(0.46)\end{array}$ & $\begin{array}{l}-0.29 \\
(0.22)\end{array}$ & $\begin{array}{l}-0.40 \\
(0.16)\end{array}$ & $\begin{array}{l}-0.46^{*} \\
(0.10)\end{array}$ & $\begin{array}{l}-0.09 \\
(0.76)\end{array}$ & $\begin{array}{l}-0.19 \\
(0.45)\end{array}$ & $\begin{array}{l}-0.15 \\
(0.71)\end{array}$ & $\begin{array}{l}-0.17 \\
(0.60)\end{array}$ \\
\hline Fast clock speed industry & $\begin{array}{l}-0.39 \\
(0.17)\end{array}$ & $\begin{array}{l}-0.32 \\
(0.20)\end{array}$ & $\begin{array}{l}-0.33 \\
(0.19)\end{array}$ & $\begin{array}{l}-0.33 \\
(0.19)\end{array}$ & $\begin{array}{l}-0.29 \\
(0.23)\end{array}$ & $\begin{array}{l}-0.37 \\
(0.11)\end{array}$ & $\begin{array}{l}-0.37 \\
(0.11)\end{array}$ & $\begin{array}{l}-0.28 \\
(0.21)\end{array}$ \\
\hline R\&D centres & $\begin{array}{l}0.44^{*} \\
(0.08)\end{array}$ & $\begin{array}{l}0.31 \\
(0.13)\end{array}$ & $\begin{array}{l}0.28 \\
(0.17)\end{array}$ & $\begin{array}{l}0.28 \\
(0.18)\end{array}$ & $\begin{array}{l}0.51 * * * \\
(0.01)\end{array}$ & $\begin{array}{l}0.36^{*} \\
(0.07)\end{array}$ & $\begin{array}{l}0.37^{*} \\
(0.08)\end{array}$ & $\begin{array}{l}0.42^{* *} \\
(0.03)\end{array}$ \\
\hline Toyota investment & $\begin{array}{l}0.54 \\
(0.11)\end{array}$ & $\begin{array}{l}0.52^{*} \\
(0.06)\end{array}$ & $\begin{array}{l}0.56^{* *} \\
(0.05)\end{array}$ & $\begin{array}{l}0.64 * * \\
(0.02)\end{array}$ & $\begin{array}{l}0.49^{*} \\
(0.07)\end{array}$ & $\begin{array}{l}0.39 \\
(0.17)\end{array}$ & $\begin{array}{l}0.37 \\
(0.29)\end{array}$ & $\begin{array}{l}0.38 \\
(0.18)\end{array}$ \\
\hline Competitor investment & $\begin{array}{l}0.49^{*} \\
(0.07)\end{array}$ & $\begin{array}{l}-0.30 \\
(0.29)\end{array}$ & $\begin{array}{l}-0.37 \\
(0.22)\end{array}$ & $\begin{array}{l}-0.35 \\
(0.25)\end{array}$ & $\begin{array}{l}0.55^{* * * *} \\
(0.01)\end{array}$ & $\begin{array}{l}-0.22 \\
(0.41)\end{array}$ & $\begin{array}{l}-0.20 \\
(0.57)\end{array}$ & $\begin{array}{l}0.01 \\
(0.98)\end{array}$ \\
\hline \multicolumn{9}{|l|}{ Explanatory variable: } \\
\hline Supplier hybrid capabilities & - & $\begin{array}{l}1.16^{* * *} \\
(0.00)\end{array}$ & $\begin{array}{l}1.18 * * * \\
(0.00)\end{array}$ & $\begin{array}{l}1.49 * * * \\
(0.00)\end{array}$ & - & $\begin{array}{l}0.76^{* * *} \\
(0.01)\end{array}$ & $\begin{array}{l}0.74 * * \\
(0.02)\end{array}$ & $\begin{array}{l}1.08 * * * \\
(0.00)\end{array}$ \\
\hline \multicolumn{9}{|l|}{ Moderator variable: } \\
\hline Alliance partner diversity & - & - & $\begin{array}{l}0.25 \\
(0.48)\end{array}$ & $\begin{array}{l}0.41 \\
(0.26)\end{array}$ & - & - & $\begin{array}{l}-0.05 \\
(0.91)\end{array}$ & $\begin{array}{l}0.07 \\
(0.85)\end{array}$ \\
\hline $\begin{array}{l}\text { Interaction effects: } \\
\text { Supplier hybrid capabilities } \\
\text { X alliance partner diversity }\end{array}$ & - & - & - & $\begin{array}{l}-0.46^{* * *} \\
(0.01)\end{array}$ & - & - & - & $\begin{array}{l}-0.36^{* * *} \\
(0.01)\end{array}$ \\
\hline Log likelihood statistic & -264.91 & -252.60 & -252.35 & -250.21 & -256.71 & -249.77 & -249.76 & -246.77 \\
\hline LR chi-square statistic & $22.32 * * *$ & $46.92 * * *$ & $47.43 * * *$ & $51.70 * * *$ & $29.91 * * *$ & $43.81 * * *$ & $43.82 * * *$ & $49.80 * * *$ \\
\hline Vuong test statistic & - & - & - & - & $1.66 * *$ & 0.77 & 0.65 & 0.94 \\
\hline Vuong test ( $p$ value) & - & - & - & - & $(0.05)$ & $(0.22)$ & $(0.26)$ & $(0.17)$ \\
\hline $\mathrm{N}$ & 143 & 143 & 143 & 143 & 143 & 143 & 143 & 143 \\
\hline
\end{tabular}

NB: Negative binomial regression models; ZINB: Zero-inflated negative binomial regression models 
Table 4

The relationship between supplier fuel cell capabilities and eco-innovation co-patenting

\begin{tabular}{|c|c|c|c|c|c|c|c|c|}
\hline & $\begin{array}{c}\text { Model } 1 \\
(\mathrm{NB})\end{array}$ & $\begin{array}{c}\text { Model } 2 \\
(\mathrm{NB})\end{array}$ & $\begin{array}{c}\text { Model } 3 \\
(\mathrm{NB})\end{array}$ & $\begin{array}{c}\text { Model } 4 \\
(\mathrm{NB})\end{array}$ & $\begin{array}{c}\text { Model } 5 \\
(\text { ZINB) }\end{array}$ & $\begin{array}{c}\text { Model } 6 \\
(\text { ZINB) }\end{array}$ & $\begin{array}{c}\text { Model } 7 \\
(\text { ZINB) }\end{array}$ & $\begin{array}{c}\text { Model } 8 \\
(\mathrm{ZINB}) \\
\end{array}$ \\
\hline \multicolumn{9}{|l|}{ Control variables: } \\
\hline Firm size & $\begin{array}{l}0.38 \\
(0.22)\end{array}$ & $\begin{array}{l}0.36 \\
(0.24)\end{array}$ & $\begin{array}{l}0.32 \\
(0.30)\end{array}$ & $\begin{array}{l}0.32 \\
(0.30)\end{array}$ & $\begin{array}{l}-0.10 \\
(0.65)\end{array}$ & $\begin{array}{l}-0.13 \\
(0.55)\end{array}$ & $\begin{array}{l}-0.15 \\
(0.50)\end{array}$ & $\begin{array}{l}-0.14 \\
(0.51)\end{array}$ \\
\hline Firm age & $\begin{array}{l}-0.63 \\
(0.16)\end{array}$ & $\begin{array}{l}-0.69 \\
(0.14)\end{array}$ & $\begin{array}{l}-0.59 \\
(0.16)\end{array}$ & $\begin{array}{l}-0.60 \\
(0.16)\end{array}$ & $\begin{array}{l}-0.57^{*} \\
(0.10)\end{array}$ & $\begin{array}{l}-0.47 \\
(0.14)\end{array}$ & $\begin{array}{l}-0.49 \\
(0.15)\end{array}$ & $\begin{array}{l}-0.48 \\
(0.16)\end{array}$ \\
\hline Engine system & $\begin{array}{l}0.39 \\
(0.24)\end{array}$ & $\begin{array}{l}0.46 \\
(0.20)\end{array}$ & $\begin{array}{l}0.51 \\
(0.13)\end{array}$ & $\begin{array}{l}0.52 \\
(0.13)\end{array}$ & $\begin{array}{l}0.66^{* *} \\
(0.04)\end{array}$ & $\begin{array}{l}0.50 \\
(0.12)\end{array}$ & $\begin{array}{l}0.55^{*} \\
(0.11)\end{array}$ & $\begin{array}{l}0.56 \\
(0.11)\end{array}$ \\
\hline Module system & $\begin{array}{l}-0.20 \\
(0.45)\end{array}$ & $\begin{array}{l}-0.19 \\
(0.48)\end{array}$ & $\begin{array}{l}-0.13 \\
(0.62)\end{array}$ & $\begin{array}{l}-0.12 \\
(0.64)\end{array}$ & $\begin{array}{l}-0.27 \\
(0.12)\end{array}$ & $\begin{array}{l}-0.27^{*} \\
(0.09)\end{array}$ & $\begin{array}{l}-0.26 \\
(0.12)\end{array}$ & $\begin{array}{l}-0.25 \\
(0.13)\end{array}$ \\
\hline Market competition & $\begin{array}{l}-0.25 \\
(0.46)\end{array}$ & $\begin{array}{l}-0.36 \\
(0.37)\end{array}$ & $\begin{array}{l}-0.47 \\
(0.21)\end{array}$ & $\begin{array}{l}-0.51 \\
(0.19)\end{array}$ & $\begin{array}{l}-0.09 \\
(0.76)\end{array}$ & $\begin{array}{l}0.15 \\
(0.65)\end{array}$ & $\begin{array}{l}0.08 \\
(0.83)\end{array}$ & $\begin{array}{l}0.04 \\
(0.92)\end{array}$ \\
\hline Fast clock speed industry & $\begin{array}{l}-0.39 \\
(0.17)\end{array}$ & $\begin{array}{l}-0.36 \\
(0.22)\end{array}$ & $\begin{array}{l}-0.56^{*} \\
(0.08)\end{array}$ & $\begin{array}{l}-0.57^{*} \\
(0.08)\end{array}$ & $\begin{array}{l}-0.29 \\
(0.23)\end{array}$ & $\begin{array}{l}-0.34 \\
(0.15)\end{array}$ & $\begin{array}{l}-0.37 \\
(0.13)\end{array}$ & $\begin{array}{l}-0.39 \\
(0.13)\end{array}$ \\
\hline R\&D centres & $\begin{array}{l}0.44^{*} \\
(0.08)\end{array}$ & $\begin{array}{l}0.44^{*} \\
(0.09)\end{array}$ & $\begin{array}{l}0.35 \\
(0.15)\end{array}$ & $\begin{array}{l}0.34 \\
(0.17)\end{array}$ & $\begin{array}{l}0.51 * * * \\
(0.01)\end{array}$ & $\begin{array}{l}0.50 * * * \\
(0.00)\end{array}$ & $\begin{array}{l}0.49 * * * \\
(0.00)\end{array}$ & $\begin{array}{l}0.47 * * * \\
(0.01)\end{array}$ \\
\hline Toyota investment & $\begin{array}{l}0.54 \\
(0.11)\end{array}$ & $\begin{array}{l}0.62 * \\
(0.10)\end{array}$ & $\begin{array}{l}0.66^{* *} \\
(0.05)\end{array}$ & $\begin{array}{l}0.68 * * \\
(0.04)\end{array}$ & $\begin{array}{l}0.49 * \\
(0.07)\end{array}$ & $\begin{array}{l}0.31 \\
(0.28)\end{array}$ & $\begin{array}{l}0.35 \\
(0.24)\end{array}$ & $\begin{array}{l}0.37 \\
(0.25)\end{array}$ \\
\hline Competitor investment & $\begin{array}{l}0.49 * \\
(0.07)\end{array}$ & $\begin{array}{l}0.41 \\
(0.18)\end{array}$ & $\begin{array}{l}-0.05 \\
(0.89)\end{array}$ & $\begin{array}{l}-0.06 \\
(0.88)\end{array}$ & $\begin{array}{l}0.55^{* * * *} \\
(0.01)\end{array}$ & $\begin{array}{l}0.67 * * * \\
(0.00)\end{array}$ & $\begin{array}{l}0.57 * * \\
(0.05)\end{array}$ & $\begin{array}{l}0.56^{*} \\
(0.06)\end{array}$ \\
\hline Explanatory variable: & & & & & & & & \\
\hline Supplier fuel cell capabilities & - & $\begin{array}{l}0.16 \\
(0.59)\end{array}$ & $\begin{array}{l}-0.10 \\
(0.75)\end{array}$ & $\begin{array}{l}-0.52 \\
(0.61)\end{array}$ & - & $\begin{array}{l}-0.18 \\
(0.30)\end{array}$ & $\begin{array}{l}-0.21 \\
(0.27)\end{array}$ & $\begin{array}{l}-0.40 \\
(0.45)\end{array}$ \\
\hline Moderator variable: & & & & & & & & \\
\hline Alliance partner diversity & - & - & $\begin{array}{l}0.91^{*} \\
(0.06)\end{array}$ & $\begin{array}{l}0.99 * \\
(0.06)\end{array}$ & - & - & $\begin{array}{l}0.20 \\
(0.53)\end{array}$ & $\begin{array}{l}0.23 \\
(0.49)\end{array}$ \\
\hline $\begin{array}{l}\text { Interaction effects: } \\
\text { Supplier fuel cell capabilities } \\
\text { X alliance partner diversity }\end{array}$ & - & - & - & $\begin{array}{l}0.13 \\
(0.67)\end{array}$ & - & - & - & $\begin{array}{l}0.06 \\
(0.70)\end{array}$ \\
\hline Log likelihood statistic & -264.91 & -264.74 & -262.78 & -262.70 & -256.71 & -256.30 & -256.09 & -256.01 \\
\hline LR chi-square statistic & $22.32 * * *$ & $22.66^{* * *}$ & $26.57 * * *$ & $26.73 * * *$ & $29.91 * * *$ & $30.74 * * *$ & $31.16^{* * *}$ & $31.31 * * *$ \\
\hline Vuong test statistic & - & - & - & - & $1.66^{* *}$ & $1.51 *$ & 1.21 & 1.22 \\
\hline Vuong test ( $p$ value) & - & - & - & - & $(0.05)$ & $(0.07)$ & $(0.11)$ & $(0.11)$ \\
\hline $\mathrm{N}$ & 143 & 143 & 143 & 143 & 143 & 143 & 143 & 143 \\
\hline
\end{tabular}

NB: Negative binomial regression models; ZINB: Zero-inflated negative binomial regression model. 
Table 5

Automaker comparison: The relationship between supplier electric capabilities and eco-innovation co-patenting amongst Japanese automakers

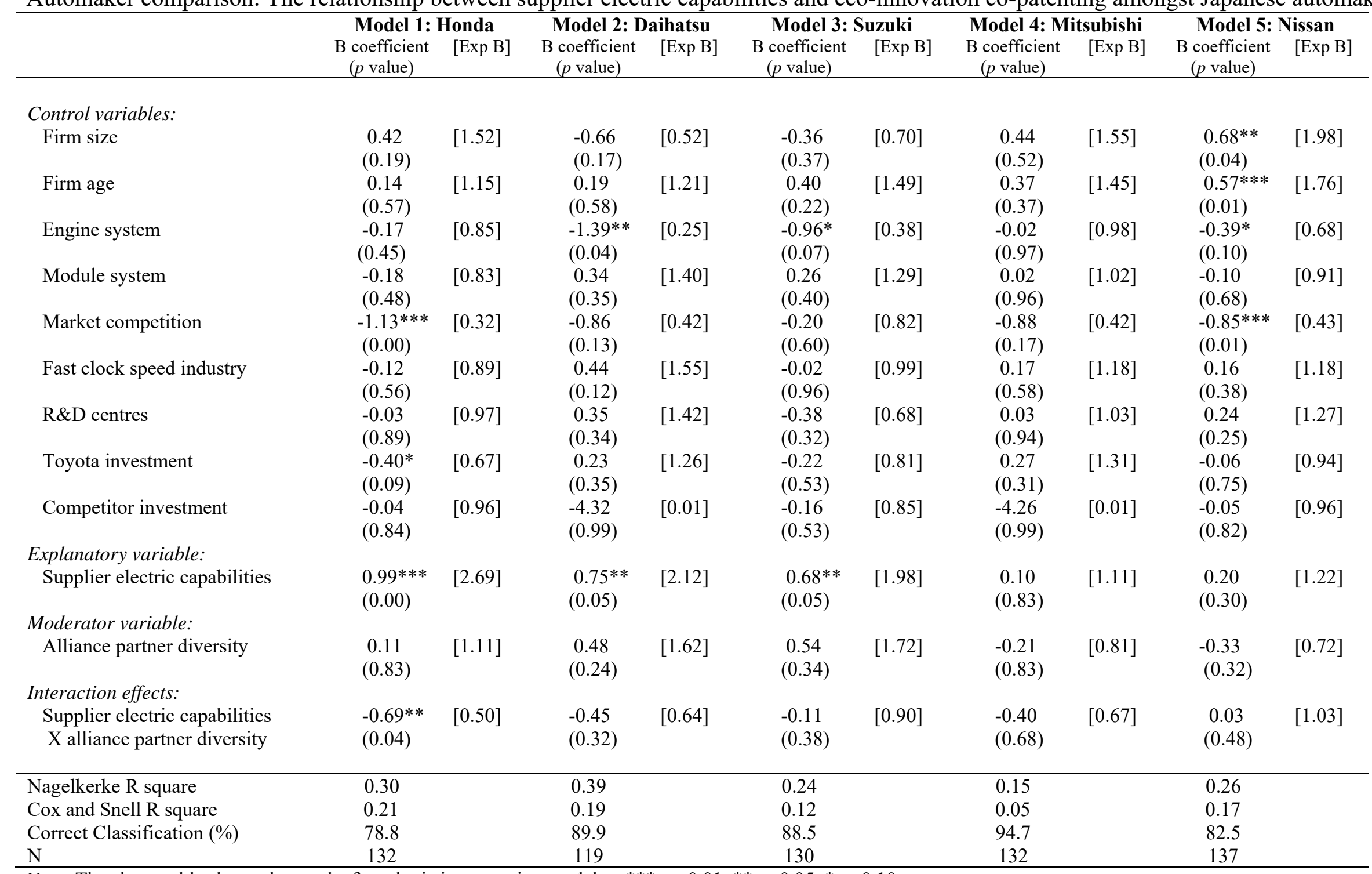

Note: The above table shows the results from logistic regression models. $* * * \mathrm{p}<0.01,{ }^{* *} \mathrm{p}<0.05, * \mathrm{p}<0.10$ 
Table 6

Automaker comparison: The relationship between supplier hybrid capabilities and eco-innovation co-patenting amongst Japanese automakers

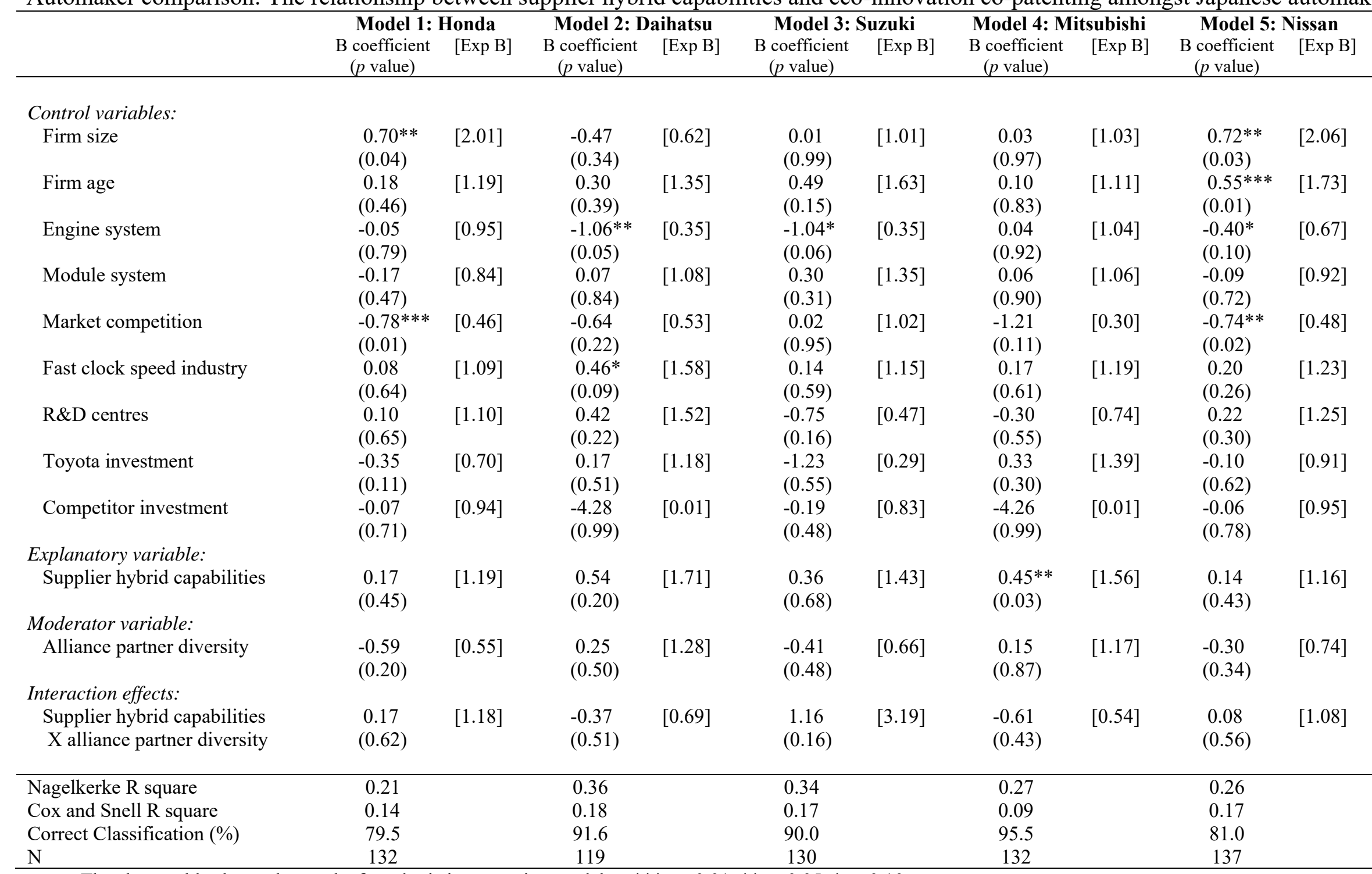

Note: The above table shows the results from logistic regression models. $* * * \mathrm{p}<0.01,{ }^{* *} \mathrm{p}<0.05,{ }^{*} \mathrm{p}<0.10$. 
Table 7

Automaker comparison: The relationship between supplier fuel cell capabilities and eco-innovation co-patenting amongst Japanese automakers

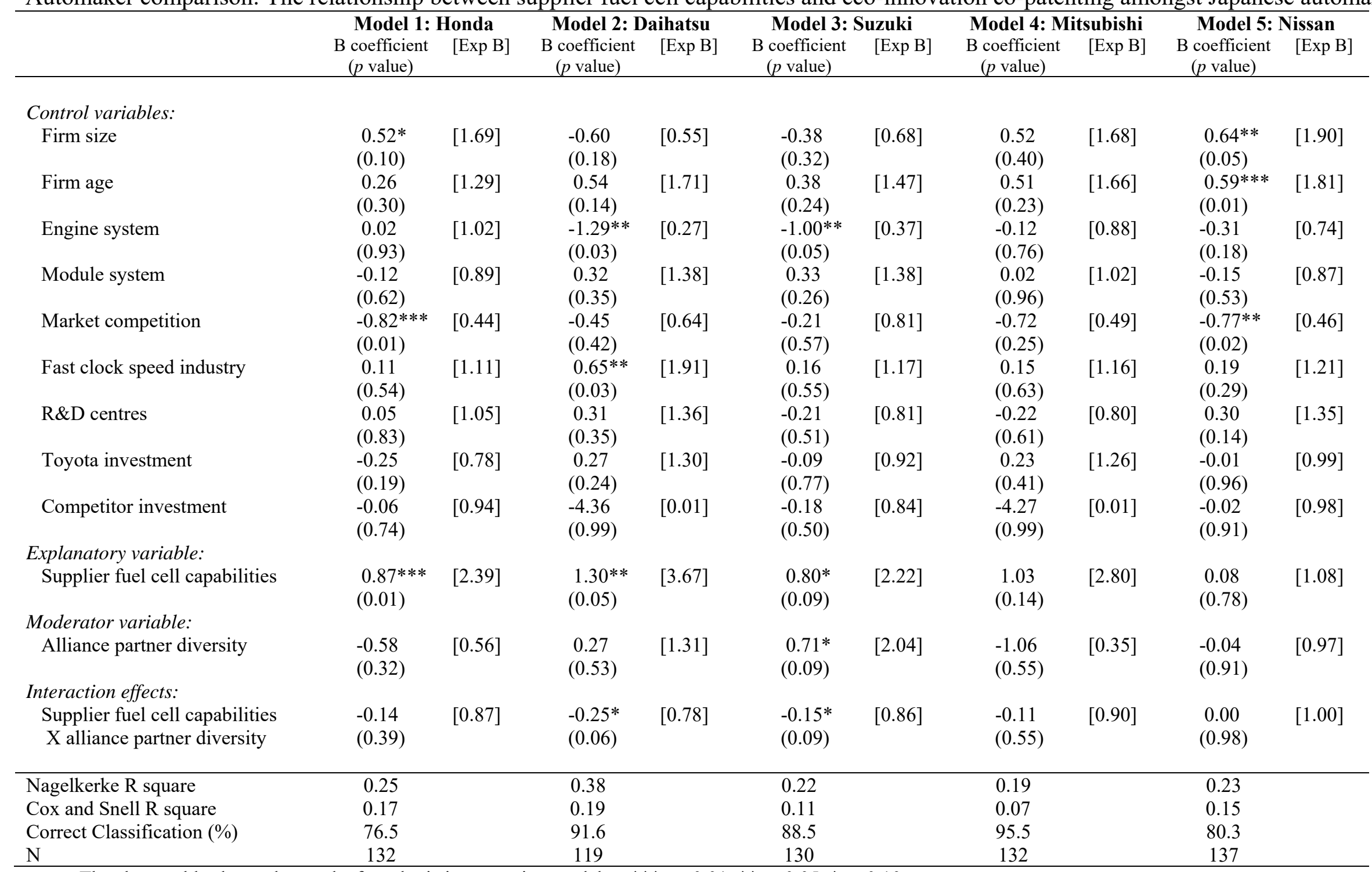

Note: The above table shows the results from logistic regression models. $* * * \mathrm{p}<0.01,{ }^{* *} \mathrm{p}<0.05,{ }^{*} \mathrm{p}<0.10$. 
Fig. 1. Conceptual framework

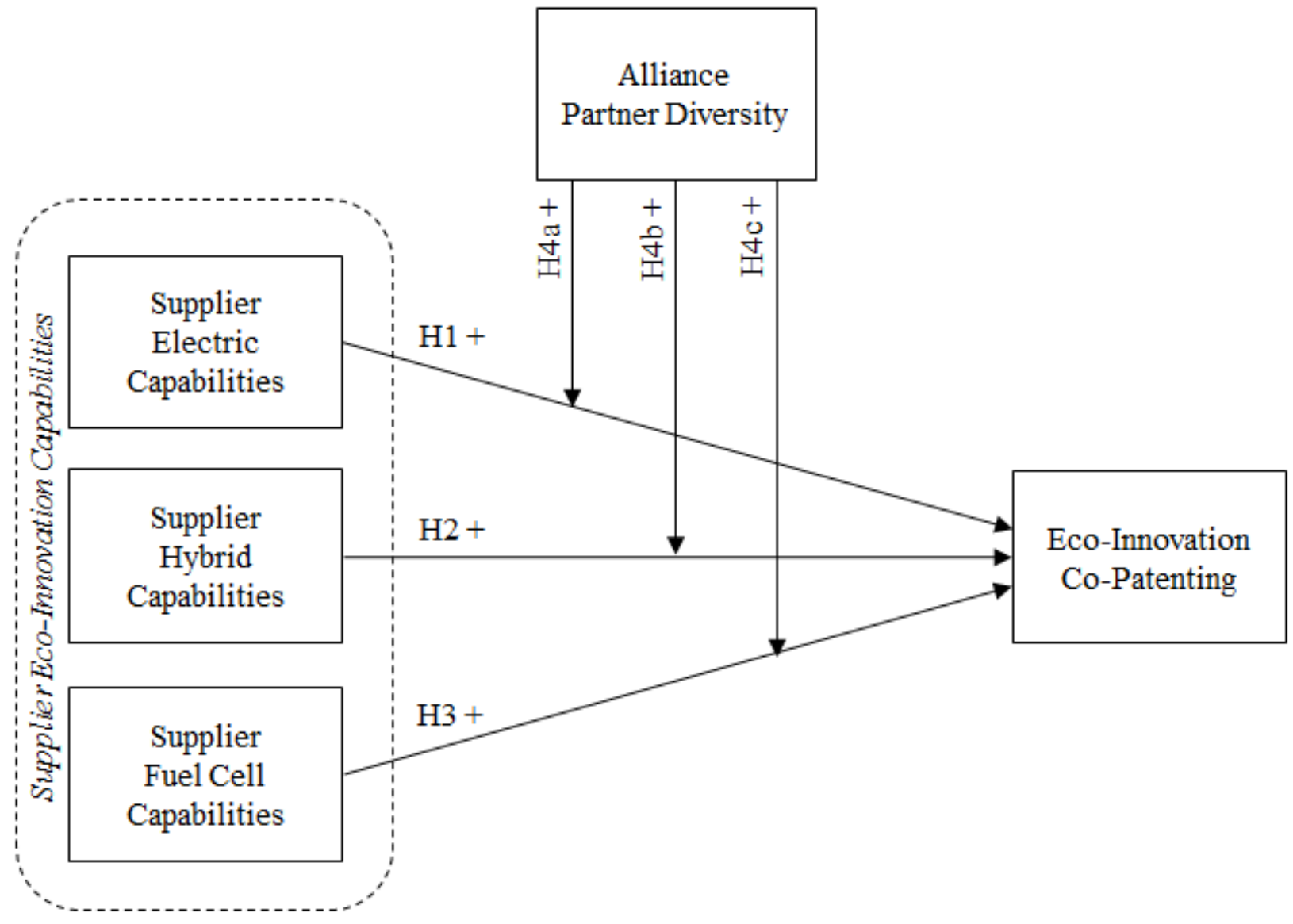

Fig. 2. Toyota's electric, hybrid and fuel cell vehicle platforms (Toyota, 2016)

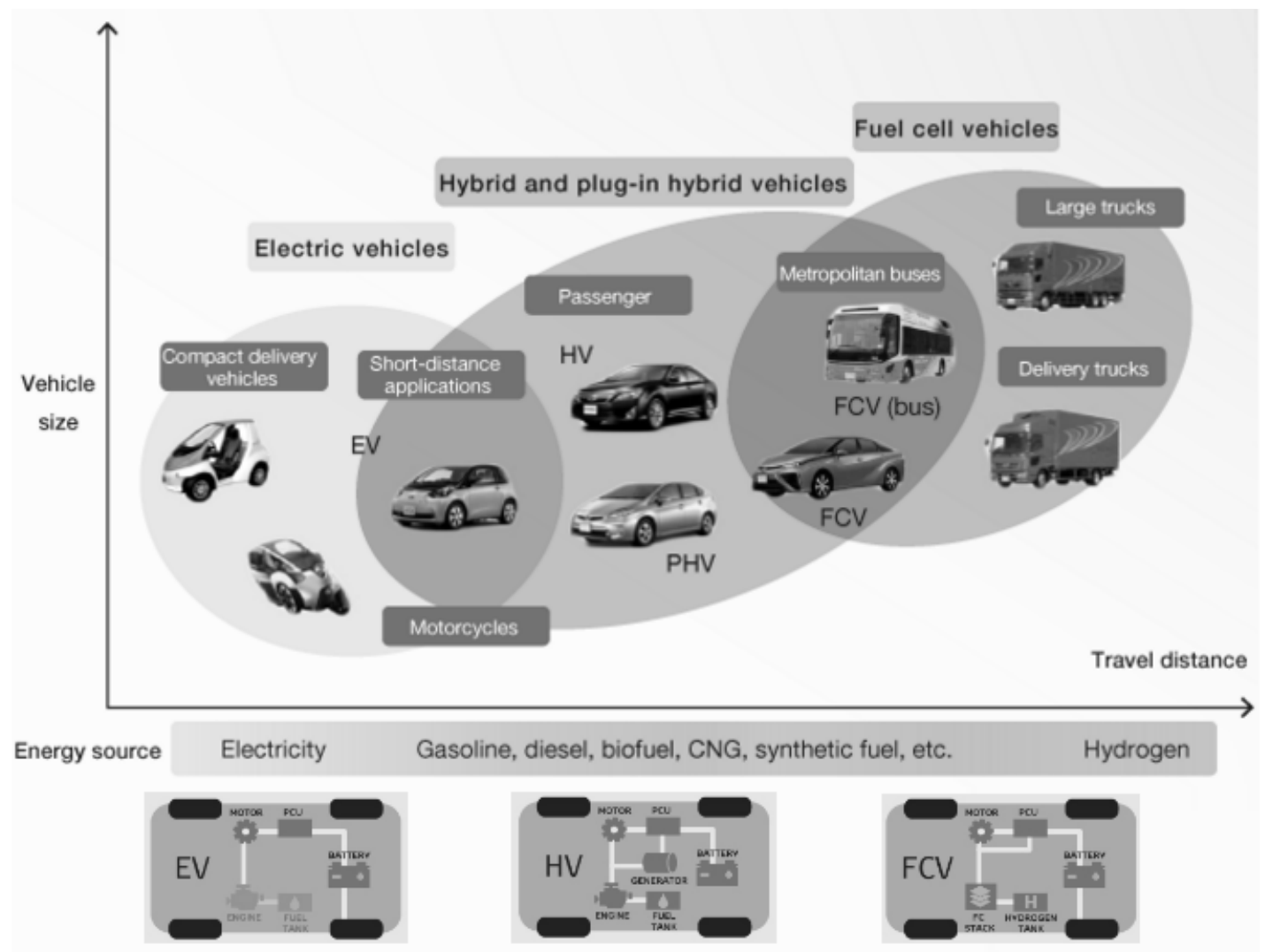


Fig. 3. The moderating effect of alliance partner diversity on the relationship between supplier electric capabilities and eco-innovation co-patenting

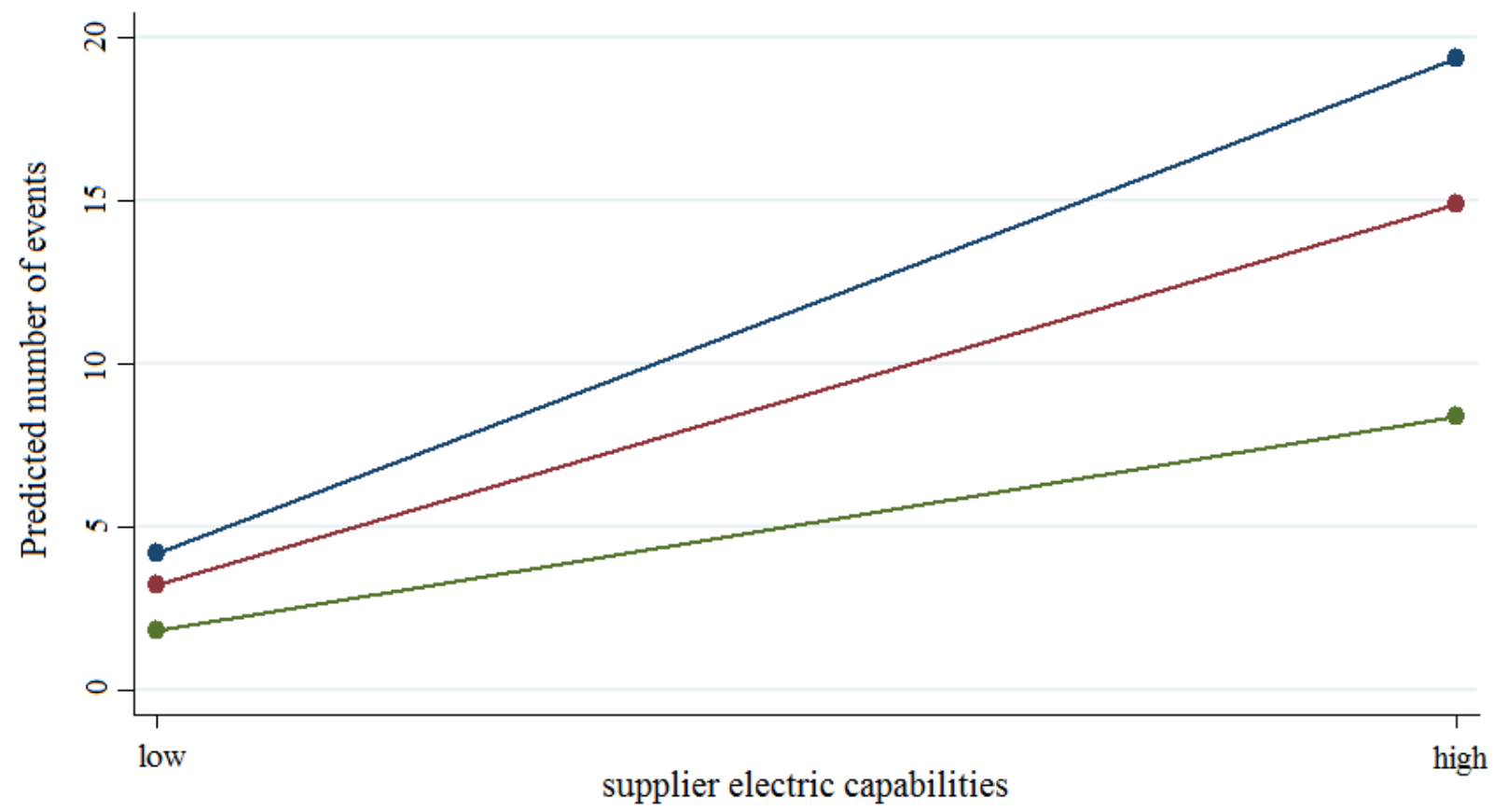
pplier electric capabilities

Fig. 4. The moderating effect of alliance partner diversity on the relationship between supplier hybrid capabilities and eco-innovation co-patenting

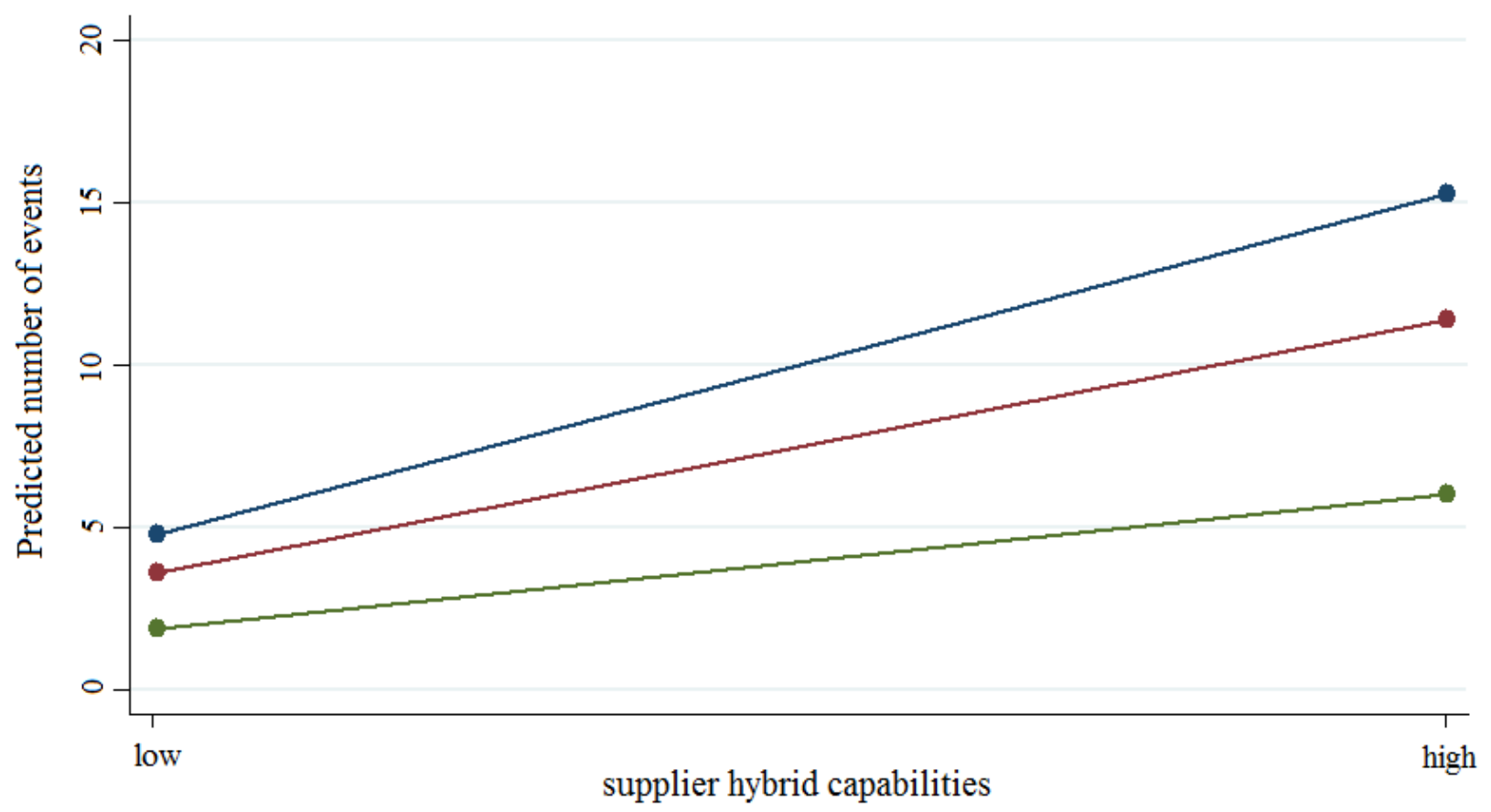

